NBER WORKING PAPER SERIES

\title{
LABOR MARKET DISCRIMINATION AND \\ RACIAL DIFFERENCES IN PREMARKET FACTORS
}

\author{
Pedro Carneiro \\ James J. Heckman \\ Dimitriy V. Masterov \\ Working Paper 10068 \\ http://www.nber.org/papers/w10068 \\ NATIONAL BUREAU OF ECONOMIC RESEARCH \\ 1050 Massachusetts Avenue \\ Cambridge, MA 02138 \\ October 2003
}

This research was supported by a grant from the American Bar Foundation and NIH R01-HD043411. Carneiro was supported by Fundacao Ciencia e Tecnologia and Fundacao Calouste Gulbenkian. We thank Derek Neal for comments and Maria Isabel Larenas, Maria Victoria Rodriguez and Xing Zhong for excellent research assistance. The views expressed herein are those of the authors and not necessarily those of the National Bureau of Economic Research.

(C)2003 by Pedro Canreiro, James J. Heckman, and Dimitriy V. Masterov. All rights reserved. Short sections of text, not to exceed two paragraphs, may be quoted without explicit permission provided that full credit, including (C) notice, is given to the source. 
Labor Market Discrimination and Racial Differences in Premarket Factors

Pedro Carneiro, James J. Heckman, and Dimitriy V. Masterov

NBER Working Paper No. 10068

October 2003

JEL No. J31

\section{ABSTRACT}

This paper examines minority-white wage gaps. Neal and Johnson (1996) show that controlling for ability measured in the teenage years eliminates young adult wage gaps for all groups except for black males, for whom they eliminate $70 \%$ of the gap. Their study has been faulted because minority children and their parents may have pessimistic expectations about receiving fair rewards for their skills and so they may invest less in skill formation. If this is the case, discrimination may still affect wages, albeit indirectly, though it would appear that any racial differences in wages are due to differences in acquired traits.

We find that gaps in ability across racial and ethnic groups open up at very early ages, long before child expectations are likely to become established. These gaps widen with age and schooling for Blacks, but not for Hispanics which indicates that poor schools and neighborhoods cannot be the principal factors affecting the slow black test score growth rate.

Test scores depend on schooling attained at the time of the test. Adjusting for racial and ethnic differences in schooling attainment at the age the test is taken reduces the power of measured ability to shrink wage gaps for blacks, but not for other minorities.

The evidence from expectations data are mixed. Although all groups are quite optimistic about future schooling outcomes, minority parents and children have more pessimistic expectations about child schooling relative to white children and their parents when their children are young. At later ages, expectations are more uniform across racial and ethnic groups. However, we also present some evidence that expectations data are unreliable and ambiguous.

We also document the presence of disparities in noncognitive traits across racial and ethnic groups. These characteristics have been shown elsewhere to be important for explaining the labor market outcomes of adults.

This evidence points to the importance of early (preschool) family factors and environments in explaining both cognitive and noncognitive ability differentials by ethnicity and race. Policies that foster both types of ability are far more likely to be effective in promoting racial and ethnic equality for most groups than are additional civil rights and affirmative action policies targeted at the workplace.

Pedro Carneiro

Department of Economics

University College London

Gower Street

London WC1E 6BT

United Kingdom

klmcarn@lily.src.uchicago.edu
James J. Heckman

Department of Economics

University of Chicago

1126 East $59^{\text {th }}$ Street

Chicago, IL 60637

and NBER

jjh@uchicago.edu
Dimitriy V. Masterov

Irving B. Harris School

Center for Social Program Evaluation

University of Chicago

1155 E. $60^{\text {th }}$ Street, Room 038

Chicago, IL 60637

dvmaster@lily.src.uchicago.edu 


\section{Introduction}

In spite of 40 years of civil rights and affirmative action policy, substantial gaps remain in the market wages of African-American males and females compared to white males and females. There are sizable wage gaps for Hispanics as well. ${ }^{1}$ Columns I of table 1 report the mean hourly log wage gaps for a cohort of black and Hispanic males and females. These gaps are for a cohort of young persons age 26-28 in 1990 from the National Longitudinal Survey of Youth of 1979, or NLSY79. We follow the cohort for 10 years until it reaches age 36-38 in 2000. These gaps are not adjusted for differences in schooling, ability, or other potential sources of racial and ethnic wage differentials.

Table 1 shows that, on average, black males earn 25\% lower wages than white males in 1990. Hispanic males earn $17.4 \%$ lower wages in the same year. Moreover, the gaps widen for males as the cohort ages. The results for women reveal smaller gaps for blacks and virtually no gap at all for Hispanic women. ${ }^{2}$ The gaps for women show no clear trend with age. Altonji and Blank (1999) report similar patterns using data from the Current Population Survey (CPS).

These gaps are consistent with the claims of pervasive labor market discrimination against many minorities, namely, that minority workers with the same ability and training as white workers receive lower wages. However, there is another equally congruous explanation. Minorities may bring less skill and ability to the market. Although there may be discrimination or disparity in the development of these valuable skills, the skills may be rewarded equally across all demographic groups in the labor market.

\footnotetext{
${ }^{1}$ The literature on African-American economic progress over the $20^{\text {th }}$ century is surveyed in Heckman and Todd (2001).

${ }^{2}$ However, the magnitude (but not the direction) of the female gaps is less reliable, at least for black women. Neal (2003) shows that racial wage gaps for black women are underestimated by these types of regressions since they do not control for selective labor force participation. This same line of reasoning is likely to hold for Hispanic women.
} 
These two interpretations of market wage gaps have profoundly different policy implications. If persons of identical skill are treated differently on the basis of race or ethnicity, a more vigorous enforcement of civil rights and affirmative action in the marketplace may be warranted. If the gaps are due to unmeasured abilities and skills that people bring to the labor market, then a redirection of policy towards fostering skills should be emphasized as opposed to a policy of ferreting out discrimination in the workplace.

An important paper by Derek Neal and William Johnson (1996) sheds light on the relative empirical importance of market discrimination and skill disparity in accounting for wage gaps by race. Controlling for a measure of scholastic ability measured in the middle teenage years, they substantially reduce but do not fully eliminate wage gaps for black males in 1990-1991. They more than eliminate the gaps for black females. Columns II of tables 1 show our version of the Neal-Johnson study, ${ }^{3}$ expanded to cover additional years. For black males, controlling for an early measure of ability cuts the wage gap in 1990 by 76 percent. For Hispanic males, controlling for ability essentially eliminates it. For women the results are even more striking. Wage gaps are actually reversed, and controlling for ability leads to higher wages for minority females.

Following Neal and Johnson, these adjustments do not control for racial and economic differences in schooling, occupational choice, or work experience. Neal and Johnson argue that racial and ethnic differences in these factors may reflect responses to labor market discrimination and should not be controlled for in estimating the full effect of race on wages since this may spuriously reduce estimated wage gaps by introducing a proxy for discrimination into the control variables. They further argue

\footnotetext{
${ }^{3}$ We use a sample very similar to the one used in their study. It includes individuals born only in 1962-1964. This exclusion is designed to alleviate the effects of differential schooling at the test date on test performance and to ensure that the $A F Q T$ test is taken before the individuals enter the labor market (i.e., so that it is a premarket factor).
} 
that ability measured in the teenage years is a "premarket" factor, meaning that it is not affected by expectations or actual experiences of discrimination in the labor market. We consider this claim and argue that there is considerable arbitrariness in proclaiming what is or is not a "premarket" factor, and such determinations matter greatly for the size of the adjusted wage gaps. When adjustments for schooling attainment at the date of the test are made, the adjusted wage gaps rise.

Gaps in measured ability by ethnicity and race are indeed substantial. In figures $1 \mathrm{~A}$ and $1 \mathrm{~B}$ we have plotted the ability distribution as measured by age-corrected $\mathrm{AFQT}^{4}$ for men and women, respectively. These differences are not small. As noted by Herrnstein and Murray (1994), the ability gaps are a major factor in accounting for a variety of racial and ethnic disparities in socioeconomic outcomes. For example, Cameron and Heckman (2001) show that controlling for ability, blacks and Hispanics are more likely to enter college than are whites at a time when wage premia for education are rising considerably. ${ }^{5}$

The evidence in columns II of table 1 suggests that the major source of minority-majority differences in wages is the disparity in characteristics that minorities bring to the market rather than discrimination in the workplace. At first glance, the evidence in the table suggests that there is no racial or ethnic disparity in market payments for comparable levels of skill for all but black males.

Though the facts displayed in table 1 and figures 1A-B are provocative, they are controversial

\footnotetext{
${ }^{4}$ Age-corrected AFQT is the standardized residual from the regression of the AFQT score on age at the time of the test dummy variables. AFQT is a subset of 4 out of 10 ASVAB tests used by the military for enlistment screening and job assignment. It is the summed score from the word knowledge, paragraph comprehension, mathematics knowledge, and arithmetic reasoning ASVAB tests.

${ }^{5}$ Urzua (2003) shows that this effect arises from greater minority enrollment in two-year colleges. Controlling for ability, whites are more likely to attend and graduate from four year colleges. Using the Current Population Survey, Black and Sufi (2002) find that equating the family background of blacks and whites eliminates the black-white gap in schooling only at the bottom of the family background distribution. Furthermore, the gaps are eliminated in the 1980 s, but not in the 1990s.
} 
for a number of reasons. The major points of contention are as follows.

1. The gaps in ability evident in figures 1A-B may stem from lowered academic effort in anticipation of future discrimination in the labor market. If skills are not rewarded fairly, the incentive to acquire them is diminished for those subject to prejudicial treatment. Discrimination in the labor market might not only sap the incentives of children and young adults to acquire skills and abilities, but it may also influence the efforts they exert in raising their own offspring. This means that measured ability may not be a true premarket factor. Neal and Johnson (1996) mention this qualification in their original paper and their critics have subsequently reiterated it.

2. The gaps in ability may also be a consequence of adverse environments, and thus the appropriate policy for eliminating ability gaps is not apparent from table 1. Should policies focus on early ages through enriched Head Start programs or on improving schooling quality and reducing school dropout and repetition rates that plague minority children at later ages?

This paper provides answers to these questions. We show that:

(a) The evidence from data on parents' and children's expectations tells a mixed story. If the rewards to schooling are lower for minorities, the return to schooling is lower and minority expectations of schooling attainment should be lower. Minority child and parent expectations measured when the children are 16 and 17 about the children's schooling prospects are as optimistic as white expectations, although actual schooling outcomes of whites and minorities are dramatically different. Differential expectations at these ages cannot explain the gaps in ability evident in figures $1 \mathrm{~A}$ and $1 \mathrm{~B}$. 
For children ages 14 and below, parent and child expectations about schooling are much lower for blacks than for whites, though only slightly lower for Hispanics than for whites. All groups are still rather optimistic in light of actual subsequent schooling attendance. At these ages, differences in expectations across groups may lead to differential investments in skill formation. Still, though lower expectations may be a consequence of perceived labor market discrimination, they may also reflect child and parental perception of the lower endowments possessed by minorities.

The fact that reported expectations are so inaccurate casts some doubt about the usefulness of expectations elicited by questionnaires for testing the actual expectations governing behavior. This is compounded by ambiguity of the source of the relatively pessimistic expectations.

(b) Ability gaps open up early, often by age 1 or 2, and as a result minorities enter school with substantially lower measured ability than whites. The black-white ability gap widens as the children get older and obtain more schooling, but the contribution of formal education to the widening of the gap is small when compared to the size of the initial gap. There is a much smaller widening of the Hispanic-white gap.

This evidence implies that school-based policies are unlikely to have substantial effects on eliminating minority ability gaps. Factors that operate early in the life cycle of the child are likely to have the greatest impact on ability. Although ability gaps between blacks and whites widen with schooling, the effect of formal schooling on ability is much smaller for blacks than for whites, and about the same for Hispanics and whites. The early emergence of ability gaps indicates that child expectations can play only a limited role in accounting for ability gaps since very young children are unlikely to have formed expectations about labor 
market discrimination or to take decisions based on those expectations. However, parental expectations of future discrimination may still play a role.

The early emergence of measured ability differentials also casts doubt on the empirical importance of the "stereotype threat" (see Steele and Aronson, 1998) as a major factor contributing to black-white test score differentials. The literature on this topic finds that black college students at selective colleges perform worse on tests when they are told that the outcomes will be used in some way to measure black-white ability differences, i.e., that the test may be used to confirm stereotypes about black-white ability differentials. However, the children in our data are tested at a young age and are unlikely to be aware of stereotypes about minority inferiority or be affected by the stereotype threat which has only been established for students at elite college. In addition, large gaps in tests are also evident for Hispanics, a group for whom the stereotype threat has not been documented.

(c) We find that differences in levels of schooling at the date the test is taken play a sizable role in accounting for ability differentials. Adjusting for the schooling attainment of minorities at the time that they take the test provides a potential qualification to the Neal and Johnson finding. Part of the ability gap demonstrated by Neal and Johnson is due to differential schooling attainment. An extra year of schooling has a greater impact on test scores for whites and Hispanics than for blacks. Adjusting the test score for schooling disparity at the date of the test raises the estimated wage gap and leaves more room for an interpretation of labor market discrimination.

This finding does not necessarily overturn the conclusion of the Neal-Johnson analysis. At issue is the source of the gap in schooling attainment at the date of the test. Our analysis 
reveals that the amount of the wage gap that is explained by discrepancies in scholastic ability depends on the age and grade completed at the date of measurement of ability. Tests adjusted for schooling explain less of the black-white wage gap compared to the unadjusted tests. The Neal-Johnson "pre-market" factors are a composite of ability and schooling, and are likely to reflect both the life cycle experiences and the expectations of the child. To the extent that they reflect expectations of discrimination as embodied in schooling that affects test scores, test scores are contaminated by market discrimination and are not truly premarket factors. An open question is how much of the gap in schooling is due to expectations about discrimination. For black males premarket factors account for half of the black-white wage gap for males. We argue that our adjustment is overly conservative because much of the gap in schooling and ability opens up at an early age, before expectations of labor market discrimination can be a plausible explanation. The adjustments for the effect of schooling on the test score have much weaker effects for other demographic groups.

(d) A focus on cognitive skill gaps, while traditional (see, e.g., Jencks and Phillips, 1998), misses important non-cognitive components of social and economic success. We show that noncognitive (i.e., behavioral) gaps also open up early. Previous work shows that they play an important role in accounting for market wages. Policies that focus solely on improving cognitive skills miss an important and promising determinant of socioeconomic success and disparity that can be affected by policy (Carneiro and Heckman, 2003).

Section 2 presents evidence on the evolution of test score gaps over the lifecycle of the child. Section 3 presents our evidence on how adjusting for schooling at the date of the test affects the Neal-Johnson analysis, and how schooling affects test scores differentially for minorities. Section 4 
discusses data on expectations. Section 5 presents evidence on noncognitive skills that parallels the analysis of Section 2. Section 6 concludes.

\section{Minority-White Differences in Early Test Scores and Early Environments}

The evidence presented in Section 1 suggests that a large fraction of the minority-white disparity in labor market outcomes that is frequently attributed to discrimination may be due instead to minority-white disparities in skill endowments. These skill endowments may be innate or acquired during the lifetime of an individual. In this section we summarize evidence from the literature and present original empirical work that demonstrates that minority-white cognitive skill gaps emerge early and persist through childhood and the adolescent years.

Jencks and Phillips (1998) and Duncan and Brooks-Gunn (1997), among others, document that the black-white test score gap is large for 3 and 4 year old children. Using the Children of the NLSY79 (CNLSY) survey, a variety of studies show that even after controlling for many variables like individual, family and neighborhood characteristics, the black-white test score gap is still sizable. Using the Early Childhood Longitudinal Survey (ECLS), Fryer and Levitt (2002) eliminate the black-white test score gap in math and reading for children at the time they are entering kindergarten, although not in subsequent years. However, the raw test score gaps at ages 3 and 4 are much smaller in ECLS than in CNLSY and other data sets that have been used to study this issue. These studies also document that there are large black-white differences in family environments. Ferguson (2002a) summarizes this literature and presents evidence that 
black children in the ECLS come from much poorer and less educated families than white children, and they are also more likely to grow up in single parent households. Studies summarized in Ferguson (2002b) find that the achievement gap is high even for blacks and whites attending high quality suburban schools. ${ }^{6}$ The common finding across these studies is that the black-white gap in test scores is large and that it persists even after one controls for family background variables. Children of different racial and ethnic groups grow up in strikingly different environments. Even after accounting for these environmental factors in a correlational sense, test score gaps tend to persist. Furthermore, they tend to widen with age and schooling: black children show lower ability growth with schooling or age than white children.

In this paper we present some evidence from CNLSY. ${ }^{7}$ We have also examined the ECLS and the Children of the Panel Study of Income Dynamics (CPSID) and found similar patterns. We broaden previous analyses to include Hispanic-white differentials. Figures 2A-B shows the average percentile PIAT Math ${ }^{8}$ scores for males and females in different age groups by race. Racial and ethnic gaps are found as early as ages 5 and 6 (the earliest ages at which we can measure math scores in CNLSY data). ${ }^{9}$ On average, black 5- and 6-year old boys are almost 18 percentile points below white 5 - and 6-year old boys (i.e., if the average white is at the 50th percentile of the test score distribution, the average black is at the 32nd percentile of this distribution). The gap is a bit smaller-16 percent-but still substantial for Hispanics. The finding is similar for black and Hispanic women who exhibit gaps of about 14 percent relative to whites. These findings are duplicated for

\footnotetext{
${ }^{6}$ This is commonly referred to as the "Shaker Heights study," although it analyzed many other similar neighborhoods.

${ }^{7}$ For a description of CNLSY and NLSY79 see BLS (2001).

${ }^{8}$ The PIAT Math is the abbreviation for Peabody Individual Achievement Test in Mathematics. This test measures the child's attainment in mathematics as taught in mainstream education. It consists of 84 multiple choice questions of increasing difficulty, beginning with recognizing numerals and progressing to geometry and trigonometry.

${ }^{9}$ Instead of using raw scores or standardized scores we choose to use ranks, or percentiles, since test score scales have no intrinsic meaning. Our results are not sensitive to this procedure.
} 
many other test scores and in other data sets, and are not altered if we use median test scores instead of means. Furthermore, as shown in figures 3A-B, even when we use a test taken at earlier ages, racial gaps in test scores can be found at ages 1 and 2 , though not always for women. ${ }^{10}$ In general, we find that the test score gaps emerge early and persist through adulthood.

For simplicity, we will focus on means and medians in this paper. However, figures 1A-B and 4A-B illustrate that there is considerable overlap in the distribution of test scores across groups in recent generations. Many black and Hispanic children at ages 5 and 6 score higher on a math test score than the average white child. Statements that we make about medians or means do not apply to all persons in the distributions.

Figures 2A-B also shows that the black-white percentile PIAT Math score gap widens with age. By ages 13 to 14, the average black is ranked more than 22 percentiles below the average white. In fact, it is well documented that these gaps persist until adulthood and beyond. At 13 to 14 Hispanic boys are still almost 16 points below the average white. For black and Hispanic girls, the gap widens to $21 \%$ and $16 \%$, respectively.

In summary, when blacks and Hispanics enter the labor market, on average, they have a much poorer set of skills than whites. Thus it is not surprising that their average labor market outcomes are so much worse. Furthermore, these skill gaps emerge very early in the life-cycle, persist, and if anything, widen for some groups. Initial conditions (i.e., early test scores) are very important as skill begets skill.

Even after controlling for numerous environmental and family background factors, the racial and ethnic test score gaps remain for many of these tests at ages 3 and 4, and for virtually all the

\footnotetext{
${ }^{10}$ Parts of the Body Test attempts to measure the young child's receptive vocabulary knowledge of orally presented words as a means of estimating intellectual development. The interviewer names each of ten body parts and asks the child to point to that part of the body.
} 
tests at later ages. Figures 5A-B show that, even after adjusting for measures of family background, such as family long-term or "permanent" income and mother's education, the mother's cognitive ability (as measured by age-corrected AFQT), and a measure of home environment called the home score, ${ }^{11}$ the black-white gap in percentile PIAT Math scores at ages 5-6 is almost $8 \%$, and at ages 13-14 is close to $11 \%$ for boys. Hispanic-white differentials are reduced more by such adjustments, falling to $7 \%$ at ages $5-6$ and to $4 \%$ at ages $13-14$ for boys. For other tests, differentials frequently become positive or statistically insignificant. For girls, the gaps in PIAT Math are reduced to about $5 \%$ at ages $5-6$ by the same adjustment, though the Hispanic gap falls to $4 \%$ while the black gap rises to $6 \%$ by age 13-14. Appendix tables $1 \mathrm{~A}-1 \mathrm{~B}$ report that even after controlling for different measures of home environments and child stimulation, the black-white test score gap persists even though it drops considerably. ${ }^{12}$ Measured home and family environments play an important role in the formation of these skills, although they are not the whole story. ${ }^{13}$ For females, both raw and adjusted test score gaps are smaller than for males, but the overall story is the same. ${ }^{14}$

The evidence for Hispanics tells a different story. ${ }^{15}$ Early test scores for blacks and Hispanics are similar, although Hispanics often perform slightly better. Figure 2A shows that for the PIAT

\footnotetext{
${ }^{11}$ The home score is the primary measure of the quality of a child's home environment included in CNLSY. It is composed of various measures of age-specific cognitive and emotional stimulation based on dichotomized and summed responses from the mother's self-report and interviewer observation. Some items included in the home score are number of books, magazines, toys and musical recordings, how often mother reads to child, frequency of family activities (eating, outings), methods of discipline and parenting, learning at home, television watching habits and parental expectations for the child (chores, time use), home cleanliness and safety and types of mother-child interactions.

${ }^{12}$ Results for other tests and other samples can be found in http://lily.src.uchicago.edu/ $\sim$ dvmaster/Stanford.html. Even though for some test scores early black-white test score gaps can be eliminated once we control for a large number of characteristics, it is harder to eliminate them at later ages. In the analysis presented here the most important variable in reducing the test score gap is mother's cognitive ability, as measured by the AFQT.

${ }^{13}$ However the Home Score includes variables such as the number of books, which are clearly choice variables and likely to cause problems in this regression. The variables with the largest effect on the minority-white test score gap are maternal AFQT and raw home score.

${ }^{14}$ See http://lily.src.uchicago.edu/ $\sim$ dvmaster/Stanford.html.

${ }^{15}$ We already saw that wage gaps are completely eliminated for Hispanics when we control for AFQT, while they persist for blacks.
} 
Math score the Hispanic-black gap is about 2 percentile points. ${ }^{16}$ This is much smaller than either the black-white or the Hispanic-white gap. For the PIAT Math test, the black-white gap widens dramatically, especially at later ages, but the Hispanic-white gap does not change substantially with age. For other tests, even when there is some widening of the Hispanic-white gap with age, it tends to be smaller than the widening in the black-white gap in test scores. In particular, when we look at the AFQT scores displayed in figures $1 \mathrm{~A}-\mathrm{B}$, and which are measured using individuals at ages 16-23, Hispanics clearly have higher scores than blacks. In contrast, figures 4A-B show a strong similarity between the math scores of blacks and Hispanics at ages 5 and 6 , although there are other tests where, even at these early ages, Hispanics perform significantly better than blacks. When we control for the effects of home and family environments on test scores, the Hispanic-white test score gap either decreases or is constant over time while the black-white test score tends to widen with age.

Racial ability gaps open up very early. Home and family environments at early ages, and even the mother's behavior during pregnancy, are likely to play crucial roles in the child's development, and black children grow up in significantly more disadvantaged environments than white children. Figure 6 shows the distributions of long-term or "permanent" family income for blacks, whites and Hispanics. Minority children are much more likely to grow up in low income families than are white children. Figure 7 shows the distribution of maternal education across race and ethnic groups. Even though the overlap in the distributions is large, white children have more educated mothers than do minority children. The distribution of maternal AFQT scores, shown in figure 8, is again very different for minority and white children. Maternal AFQT is a major predictor of children's

\footnotetext{
${ }^{16}$ The test score is measured in percentile rank The black-white gap is slightly below 18 while the Hispanic-white gap is slightly below 16 . This means that the black-Hispanic gap should be around 2 .
} 
test scores. ${ }^{17}$ Figure 9 document that white mothers are much more likely to read to their children at young ages than are minority mothers, and we obtain similar results at young ages. ${ }^{18}$ Using this reading variable and other variables in CNLSY such as number of books, magazines, toys and musical recordings, family activities (eating, outings), methods of discipline and parenting, learning at home, TV watching habits, parental expectations for the child (chores, time use), and home cleanliness and safety, we can construct an index of cognitive and emotional stimulation-the home score. Figure 10 shows that this index is always higher for whites than for minorities. ${ }^{19}$ Figure 11 shows that blacks are the most likely to grow up in broken homes. Hispanics are less likely than blacks to grow up in a broken home, although they are much more likely to do so than are whites. The research surveyed in Carneiro and Heckman (2003) suggests that enhanced cognitive stimulation at early ages is likely to produce some achievement test gains in children from disadvantaged environments, although long lasting effects of such interventions on IQ are not found.

The fact that racial and ethnic test score gaps open up early casts doubt on the empirical importance of the stereotype threat. It is now fashionable in some circles to attribute gaps in black test scores to racial consciousness on the part of black test takers stemming from the way test scores are used in public discourse to describe minorities. Stereotype threats could not have been important when blacks took the first IQ tests at the beginning of the twentieth century which documented the racial differentials that gave rise to the stereotype. Yet racial IQ gaps are comparable across time. ${ }^{20}$ Young children, like the ones studied in this paper, are unlikely to have the heightened racial

\footnotetext{
${ }^{17}$ For example, the correlation between percentile PIAT math score and age-corrected maternal AFQT is 0.4.

${ }^{18}$ See the results for all ages in http://lily.src.uchicago.edu/ $\sim$ dvmaster/Stanford.html.

${ }^{19}$ In http://lily.src.uchicago.edu/ dvmaster/Stanford.html, we document that both cognitive and emotional stimulation indexes are always higher for whites than for blacks at all ages.

${ }^{20}$ Murray (1999) reviews the evidence on the evolution of the black-white $I Q$ gap. In the 1920s-a time when such tests were much more unrealiable and black educational attainment much lower-the mean black-white difference was 0.86 standard deviations. The largest black-white difference appears in the 1960s, with a mean black-white difference of 1.28 standard deviations. The difference ranges from a low of 0.82 standard deviations in the 1930s to
} 
consciousness about tests and their social significance of the sort found by Steele and Aronson (1998) in college students at a few elite universities. Moreover, sizable gaps are found for young Hispanic males-a group for which the "stereotype" threat remains to be investigated.

\section{The Differential Effect of Schooling on Test Scores}

The previous section shows that cognitive test scores are correlated with home and family environments. We referenced research that suggests that test score gaps increase with age and schooling, and presented fresh evidence on this issue. The research of Hansen, Heckman and Mullen (2003) shows that the AFQT test scores used by Neal and Johnson are affected by schooling attainment of individuals at the time they take the test. Therefore, one reason for the divergence of black and white test scores over time may be differential schooling attainments. Figure 12 shows the schooling completed at the test date for the six demographic groups used in the Neal and Johnson sample. Blacks have slightly less completed schooling at test date than whites, but substantially more than Hispanics. There are substantial schooling deficits for minorities.

Table 2 presents the effect of schooling at test date on AFQT scores for individuals in different demographic groups in the NLSY, using a version of the nonparametric method developed in Hansen, Heckman and Mullen (2003). Their method isolates the causal effect of schooling attained at the test date on test scores controlling for unobserved factors that lead to selective differences in schooling attainment. This table shows clearly that the effect of schooling on test scores is much higher for whites and Hispanics than it is for blacks over most ranges of schooling. As a result, even though Hispanics have fewer years of completed schooling at the time they take the AFQT test than blacks

1.12 standard deviations in the 1970s. However, none of the samples prior to 1960 are nationally representative, and the samples were often chosen so as to effectively bias the black mean upward. 
(see figure 12), on average Hispanics score better on the AFQT than do blacks.

There are different explanations for these facts. Carneiro and Heckman (2003) suggest that one important feature of the learning process may be complementarity between endowment human capital and learning. ${ }^{21}$ Higher levels of human capital raise the productivity of learning. ${ }^{22}$ If minorities and whites start school with very different initial conditions (as documented in the previous section), their learning paths can diverge dramatically over time. Another explanation may be that blacks and non-blacks learn at different rates because blacks attend lower quality schools than whites.

Currie and Thomas (2000) show that test score gains of participants in the Head Start program tend to fade completely for blacks but not for whites. Their paper suggests that one reason may be that blacks attend worse schools than whites, and therefore blacks are not able to maintain initial test score gains. Both early advantages and disadvantages as well as school quality are likely to be important factors in the human capital accumulation process. Therefore, differential initial conditions and differential school quality may also be important determinants of the adult black-white skill gap.

In light of the greater growth in test scores of Hispanics that are parallel to those of whites, these explanations are not completely compelling. Hispanics start from similar initial disadvantages in family environments and face school and neighborhood environments similar to those faced by blacks. ${ }^{23}$ They also have early levels of test scores similar to those found in the black population.

What are the consequences of correcting for different levels of schooling at the test date? To answer this question, we reanalyze Neal and Johnson's 1996 study using AFQT scores corrected for

\footnotetext{
${ }^{21}$ For example, see the Ben-Porath (1967) model.

${ }^{22}$ See the evidence in the paper by Heckman, Lochner and Taber (1998).

${ }^{23}$ The evidence for CNLSY is presented on lily.src.uchicago.edu/ $\sim$ dvmaster/Stanford.html.
} 
the race- or ethnicity-specific effect of schooling while equalizing the years of schooling attained at the date of the test across all racial/ethnic groups. The results of this adjustment are given in table 3. This adjustment is equivalent to replacing each individual's AFQT score by the score we would measure if he or she would have stopped his or her formal education after eighth grade. (However, the score is itself already affected by attendance in kindergarten, eight further years of schooling, and any school quality differentials in those years.) In other words, we use "eighth grade" AFQT scores for everyone. Since the effect of schooling on test scores is higher for whites than for blacks, and whites have more schooling than blacks at the date of the test, this adjustment reduces the test scores of whites much more. Although the black-white male wage gap is still cut in half when we use this new measure of skill, the effect of AFQT on reducing the wage gap is weaker than in the original Neal and Johnson (1996) study. The adjustment has little effect on the Hispanic-white wage gap but a wage gap for black women emerges when using the schooling adusted measure.

This finding does not necessarily invalidate the Neal-Johnson study. It shows that schooling can partially reduce the ability gap. It raises the larger question of what a "pre-market" factor is. Neal and Johnson do not condition on schooling in explaining black-white wage gaps, arguing that schooling is affected by expectations of adverse market opportunities facing minorities and conditioning on such a contaminated variable would spuriously reduce the estimated wage gap. We present direct evidence on this claim below.

Their line of argument is not entirely coherent. If expectations of discrimination affect schooling, the very logic of their "pre-market" argument suggests that they should control for the impact of schooling on test scores when using test scores to properly account for premarket factors. As we have seen, when this is done, the wage gap (conditional on ability adjusted by schooling) widens substantially for blacks. There is still little evidence of discrimination for Hispanic females, but the 
evidence for Hispanic males comes close to demonstrating discrimination.

Implicitly, Neal and Johnson assume that schooling at the date of the test is not affected by expectations of discrimination in the market while later schooling is. This distinction is arbitrary. A deeper investigation of the expectation formation process and feedback is required. One practical conclusion with important implications for the interpretation of the evidence is that the magnitude of the wage gap one can eliminate by performing a Neal-Johnson analysis may depend on the age at which the test is measured. The earlier the test is measured, the smaller the test score gap, and the larger the fraction of the wage gap that is unexplained by the residual. Figures 13A-D show how adjusting measured ability for schooling at the test at different levels affects the adjusted wage gap for black males. For example, the log wage gap corresponding to grade of AFQT correction equal to 11 is the log wage gap we obtain when use "eleventh grade" test scores. The later the grade to which we adjust the test score, the lower the estimated gap because the greater the gap in measured ability.

Finally we show that adjusting for expectations-contaminated completed schooling does not operate in the fashion conjectured by Neal and Johnson. Table 4 shows that when we adjust wage differences for completed schooling as well as schooling-adjusted AFQT, wage gaps widen. This runs contrary to the simple intuition that schooling embodies expectations of market discrimination, so that conditioning on it will eliminate wage gaps. ${ }^{24}$

Ours is a worst-case analysis for the Neal-Johnson study. If we assign all racial and ethnic schooling differences to expectations of discrimination in the labor market, their results for blacks are

\footnotetext{
${ }^{24}$ The simple intuition, however, can easily be shown to be wrong so the evidence in these tables is not decisive on the presence of discrimination in the labor market. The basic idea is that if both schooling and the test score are correlated with an unmeasured discrimination component in the error term, the bias for the race dummy may be either positive or negative depending on the strength of the correlation among the contaminated variables and their correlation with the error term.
} 
less sharp. Yet the evidence presented in Section 2 about the early emergence of ability differentials is reinforced by the early emergence of differential grade repetition gaps by minorities (documented by Cameron and Heckman, 2001). Most of the schooling gap at the date of the test emerges in the early years, which child expectations are unlikely to be operative. Of course, one can always argue that these early schooling and ability gaps are due to parental expectations of poor labor markets for minority children. We examine data on parental expectations next.

\section{The Role of Expectations}

The argument that minorities perform worse on tests because they expect to be less well rewarded in the labor market than whites for the same test score or schooling level is implausible because expectations of labor market rewards are unlikely to affect the behavior of children as early as ages 3 or 4 when test score gaps are substantial. The argument that minorities invest less in skills because both minority children and minority parents have low expectations about their performance in school and in the labor market has mixed empirical backing.

Data on expectations are hard to find, and when they are available they are difficult to interpret. For example, in the NLSY97, black 17- and 18-year old report that the probability of dying next year is $22 \%$ while for whites it is $16 \%$. Both numbers are absurdly high. Minorities usually report higher expectations than whites of committing a crime, being incarcerated and being dead next year, and these adverse expectations may reduce their investment in human capital. Expectations reported by parents and children for the child adolescent years for a variety of outcomes are given in Table 5. Some estimates are plausible, while many others are not.

Schooling expectations measured in the late teenage years are very similar for minorities and 
whites. They are slightly lower for Hispanics. Table 6A reports the mean expected probability of being enrolled in school next year, for black, white and Hispanic 17- to 18-year old males. Among those individuals enrolled in 1997, on average whites expect to be enrolled next year with 95.7\% probability. Blacks expect that they will be enrolled next year with a $93.6 \%$ probability. Hispanics expect to be enrolled with a $91.5 \%$ probability. If expectations about the labor market were adverse for minorities, they should translate into adverse expectations for the child's education. Yet these data do not reveal this. Moreover, all groups substantially overestimate actual enrollment probabilities. The difference in expectations between blacks and whites is very small, and is less than half the difference in actual (realized) enrollment probabilities ( $81.9 \%$ for whites versus $76.4 \%$ for blacks). The gap is wider for Hispanics. Table 6B reports parental schooling expectations for white, black and Hispanic males for the same individuals used to present the numbers in Table 6A. It shows that, conditional on being enrolled in 1997 (the year the expectation question is asked), black parents expect their sons to be enrolled next year with a $90.9 \%$ probability, while for whites this expectation is $95.4 \%$. For Hispanics this number is lower (88.5\%). Parents overestimate enrollment probabilities for their sons, but black parents have lower expectations than white parents. For females the racial and ethnic differences in parental expectations are smaller than those for males. ${ }^{25}$

For expectations measured at earlier ages the story is dramatically different. Figures 14A-B show that, for the CNLSY, both black and Hispanic children and their parents have more pessimistic expectations about schooling than white children, and more pessimistic expectations may lead to lower investments in skills, less effort in schooling and lower ability. These patterns are also found in the CPSID and ECLS. ${ }^{26}$ It is curious that for CNLSY teenagers expectations seem to converge

\footnotetext{
${ }^{25}$ See http://lily.src.uchicago.edu/ $\sim$ dvmaster/Stanford.html.

${ }^{26}$ See http://lily.src.uchicago.edu/ dvmaster/Stanford.html.
} 
at later ages (see figure 14C).

If the more pessimistic expectations of minorities are a result of market discrimination, then lower investments in children that translate into lower levels of ability and skill at later ages are a result of market discrimination. Ability would not be a premarket factor. However, lower expectations for minorities may not be a result of discrimination but just a rational response to the fact that minorities do not do as well in school as whites. This may be due to environmental factors unrelated to expectations of discrimination in the labor market. Whether this phenomenon itself is a result of discrimination is an open question. Expectation formation models are very complex and often lead to multiple equilibria, and therefore they are difficult to test empirically.

Expectations are likely to play a very important role in the skill investment behavior of both parents and children. Nevertheless, they are hard to measure, and data on them are often unreliable or difficult to interpret. Across demographic groups, schooling expectations are in general unrealistically optimistic although the degree of optimism varies by age. This is true at different ages, and whether one measures expectations of parents or of their children. Since minorities perform much more poorly than whites in terms of their schooling outcomes, relative expectations (expectation minus actual probability of the event) tend to be much higher for minorities than for whites.

\section{The Evidence on Non-Cognitive Skills}

Controlling for scholastic ability in accounting for minority-majority wage gaps captures only part of the endowment differences between groups but receives most of the emphasis in the literature on black-white gaps (see Jencks and Phillips, 1998). An emerging body of evidence, summarized in Bowles, Gintis and Osborne (2001) and Carneiro and Heckman (2003), documents that noncognitive 
skills-motivation, self control, time preference, social skills-are important in explaining socioeconomic success and differentials in socioeconomic success.

Some of the best evidence for the importance of noncognitive skills in the labor market is from the GED (General Education Development) program. This program examines high school dropouts to certify that they are equivalent to high school graduates. In its own terms, the GED program is successful. Heckman and Rubinstein (2001) show that GED recipients and ordinary high school graduates who do not go on to college have the same distribution of AFQT scores (the same test that is graphed in figure 1). They are psychometrically equated. Yet GED recipients earn the wages of high school dropouts with the same number of years of completed schooling. They are more likely to quit their jobs, engage in fighting or petty crime, or to be discharged from the military, than are high school graduates who do not go on to college or other high school dropouts (see Heckman and Rubinstein, 2001). Intelligence alone is not sufficient for socioeconomic success. Minority-white gaps in noncognitive skills open up early and widen over the lifecycle.

The CNLSY has lifecycle measures of noncognitive skills. Mothers are asked age specific questions about the anti-social behavior of their children such as aggressiveness or violent behavior, cheating or lying, disobedience, peer conflicts and social withdrawal. The answers to these questions are grouped in different indices. ${ }^{27}$ Figures $15 \mathrm{~A}-\mathrm{B}$ shows that there are important racial and ethnic gaps in anti-social behavior index that emerge in early childhood. By ages 5 and 6 , the average black is roughly 10 percentile points above the average white in the distribution of this

\footnotetext{
${ }^{27}$ The children's mothers were asked 28 age-specific questions about frequency, range and type of specific behavior problems that children age four and over may have exhibited in the previous three months. Factor analysis was used to determine six clusters of questions. The responses for each cluster were then dichotomized and summed. The Antisocial Behavior index we use in this paper consists of measures of cheating and telling lies, bullying and cruelty to others, not feeling sorry for misbehaving, breaking things deliberately (if age is less than 12), disobedience at school (if age is grater than 5), and trouble getting along with teachers (if age is greater than 5).
} 
score (the higher the score, the worse the behavior). ${ }^{28}$ The results shown in Figures $16 \mathrm{~A}-\mathrm{B}-$ where we adjust the gaps by permanent family income, mother's education and age-corrected $A F Q T$ and home score-also show large reductions. ${ }^{29}$

In Section 2 we documented that minority and white children face sharp differences in family and home environments while growing up. The evidence presented in this section shows that these early environmental differences can account (in a correlational sense) for most of the minority-white gap in noncognitive skills, as measured in CNLSY.

Carneiro and Heckman (2003) document that noncognitive skills are more malleable than cognitive skills. In their paper they report that noncognitive skill gaps can be eliminated by equalization of family and home environments, while cognitive skill gaps cannot, even though they can be sharply reduced. The largest effects of interventions in childhood and adolescence are on noncognitive skills. Improvements in these skills produce better labor market outcomes, less engagement in criminal activities and other risky behavior. This is an avenue for policy that warrants much greater attention.

\section{Summary and Conclusion}

This paper discusses the sources of wage gaps between minorities and whites. For all minorities but black males, adjusting for the ability that minorities bring to the market eliminates wage gaps. The major source of economic disparity by race and ethnicity in U.S. labor markets is in endowments, not in payments to endowments.

\footnotetext{
${ }^{28}$ In http://lily.src.uchicago.edu, we show that these differences are statistically strong. Once we control for family and home environments, gaps in most behavioral indices disappear.

${ }^{29}$ See Appendix Tables 2A-2B for the effect of adjusting for other environmental characteristics on the anti-social behavior score.
} 
This evidence suggests that strengthened civil rights and affirmative action policies targeted at the labor market are unlikely to have much effect on racial and ethnic wage gaps, except possibly for those specifically targeted toward black males. Policies that foster endowments have much greater promise. On the other hand, this paper does not provide any empirical evidence on whether or not the existing edifice of civil rights and affirmative action legislation should be abolished. All of our evidence on wages is for an environment where affirmative action laws and regulations are in place.

Minority deficits in cognitive and noncognitive skills emerge early and widen. Unequal schooling, neighborhoods and peers may account for this differential growth in skills, but the main story in the data is not about growth rates but rather about the size of early deficits. Hispanic children start with cognitive and noncognitive deficits similar to those of black children. They also grow up in similar disadvantaged environments, and are likely to attend schools of similar quality. Hispanics have substantially less schooling than blacks. Nevertheless, the ability growth by years of schooling is much higher for Hispanics than blacks. By the time they reach adulthood, Hispanics have significantly higher test scores than blacks. Conditional on test scores, there is no Hispanic-white wage gap. Our analysis of the Hispanic data illuminates the traditional study of black-white differences and casts doubt on many conventional explanations of these differences since they do not apply to Hispanics who also suffer from many of the same disadvantages. The failure of the Hispanic-white gap to widen with schooling or age casts doubt on poor schools and bad neighborhoods as the reasons for the slow growth rate in black test scores, since Hispanics experience the same kinds of poor schools and bad neighborhoods experienced by blacks. Deficits in noncognitive skills can be explained (in a statistical sense) by adverse early environments; deficits in cognitive skills are less easily eliminated by the same factors.

Neal and Johnson (1996) were the first to document that endowments acquired before people 
enter the market explain most of the minority-majority wage gap. They use an ability test taken in the teenage years as a measure of endowment unaffected by discrimination. In this paper, we note that the distinction between "premarket" factors unaffected by expectations of market discrimination and "market" factors so affected is an arbitrary one. Occupational choice is likely affected by discrimination. The proper treatment of schooling is less clear-cut. Neal and Johnson purposely omit schooling in adjusting for racial and ethnic wage gaps, arguing that schooling choices are potentially contaminated by expectations of labor market discrimination. Yet they do not adjust their measure of ability by the schooling attained at the date of the test, which would be the appropriate correction if their argument were correct. The literature establishes that their measure of ability is affected by this measure of schooling.

Adjusting wage gaps by completed schooling and the adjusted test widens wage gaps for all groups, but has especially strong effects for blacks. At issue is how much of the difference in schooling at the date of the test is due to expectations of labor market discrimination and how much is due to adverse early environments. While this paper does not settle this question definitively, test score gaps emerge early and are more plausibly linked to adverse early environments. The lion's share of the ability gaps at the date of the test emerge very early, before children can have clear expectations about their labor market prospects.

The emergence of test score gaps in young children casts serious doubt on the importance of "stereotype threats" in accounting for poorer black test scores. It is implausible that young minority test takers have the social consciousness assumed in the stereotype literature.

Moreover, gaps in test scores of the magnitude found in recent studies were found in the earliest tests before the results of testing were disseminated. Effective social policy designed to eliminate racial and ethnic inequality for most minorities should focus on eliminating skill gaps, not on 
discrimination in the workplace of the early Twenty-First Century. Interventions targeted at adults are much less effective and do not compensate for early deficits. Early interventions aimed at young children hold much greater promise than strengthened legal activism in the workplace. ${ }^{30}$

${ }^{30}$ See Carneiro and Heckman (2003) for the evidence on early interventions and later remedial interventions. 


\section{References}

[1] Altonji, Joseph and Rebecca Blank, (1999). "Gender and Race in the Labor Market," in O. Ashenfelter and D. Card, Handbook of Labor Economics, Volume 3C. (New York, NY: Elsevier Science Press).

[2] Ben-Porath, Yoram (1967). "The Production of Human Capital and the Life Cycle Earnings," Journal of Political Economy, 75(4, part 1): 352-365.

[3] Black, Sandra E. and Amir Sufi (2002). "Who Goes to College? Differential Enrollment by Race and Family Background," NBER Working Paper no. w9310.

[4] Bureau of Labor Statistics (BLS) (2001). NLS Handbook 2001. Washington, D.C.: U.S. Department of Labor.

[5] Cameron, Steve and James J. Heckman, (2001). "The Dynamics of Educational Attainment for Blacks, Whites and Hispanics," Journal of Political Economy 109(3) (2001), 455-499.

[6] Carneiro, Pedro and James J. Heckman, (2003). "Human Capital Policy," Forthcoming in J. Heckman and A. Krueger (eds.), Inequality in America: What Role for Human Capital Policy? (Cambridge, MA: MIT Press).

[7] Cawley, John, James J. Heckman and Edward Vytlacil, (1999). "On Policies to Reward the Value Added by Educators," Review of Economics and Statistics, 81(4): 720-728.

[8] Currie, Janet, and Duncan Thomas. (2000). "School Quality and the Longer-Term Effects of Head Start," Journal of Human Resources, 35(4): 755-74. 
[9] Duncan, Greg, and Jeanne Brooks-Gunn. (1997). Consequences of Growing Up Poor. (New York: Russell Sage).

[10] Ferguson, Ronald (2002a), "Why America's Black-White School Achievement Gap Persists," Unpublished Manuscript, Harvard University, 2002.

[11] Ferguson, Ronald (2002b), "What Doesn't Meet the Eye: Understanding and Addressing Racial Disparities in High Achieving Suburban Schools," Special Edition, Policy Issues Report, (Naperville, IL: North Central Regional Educational Laboratory).

[12] Fryer, Roland, and Steven Levitt. (2002). "Understanding the Black-White Test Score Gap in the First Two Years of School," NBER working paper no. 8975.

[13] Hansen, Karsten, James J. Heckman and Kathleen Mullen, (2003). "The Effect of Schooling and Ability on Achievement Test Scores," Forthcoming, Journal of Econometrics.

[14] Heckman, James J., Lance Lochner and Christopher Taber, (1998). "Explaining Rising Wage Inequality: Explorations with a Dynamic General Equilibrium Model of Labor Earnings with Heterogeneous Agents," Review of Economic Dynamics, 1(1): 1-58.

[15] Heckman, James J. and Yona Rubinstein, (2001). "The Importance of Noncognitive Skills: Lessons from the GED Testing Program," American Economic Review, 91(2): 145-49.

[16] Heckman, J., J. Hsee and Y. Rubinstein (2003). "The GED is a 'Mixed Signal': The Effect of Cognitive and Noncognitive Skills on Human Capital and Labor Market Outcomes," working paper, University of Chicago. 
[17] Heckman, James J. and Petra Todd, (2001). "Understanding the Contribution of Legislation, Social Activism, Markets and Choice to the Economic Progress of African Americans in the Twentieth Century," Unpublished manuscript, American Bar Foundation, Chicago, IL.

[18] Herrnstein, Richard and Charles Murray, (1994). The Bell Curve : Intelligence and class structure in American life. (New York: Free Press).

[19] Jencks, Christopher and Meredith Phillips (1998), The Black-White Test Score Gap. (Washington, D.C.: The Brookings Institution).

[20] Murray, Charles (1999). "The Secular Increase in IQ and Longitudinal Changes in the Magnitude of the Black-White Difference: Evidence from the NLSY," paper presented to the Behavior Genetics Association Meeting.

[21] Neal, Derek (2003), "The Measured Black-White Wage Gap among Women is Too Small," working paper, University of Chicago.

[22] Neal, Derek and William Johnson (1996), "The Role of Premarket Factors in Black-White Wage Differences," Journal of Political Economy 104(5): 869-95.

[23] Steele, Claude and Joshua Aronson (1998), "Stereotype Threat and the Test Performance of Academically Successful African Americans," in C. Jencks and M. Phillips, eds., The BlackWhite Test Score Gap, (Washington, DC: The Brookings Institution), pp. 401-427..

[24] Urzua, Sergio (2003), "The Educational White-Black Gap: Evidence on Years of Schooling", Unpublished manuscript, University of Chicago, Department of Economics. 
Table 1

Change in the Black-White Log Wage Gap Induced by Controlling for Age-Corrected AFQT in 1990-2000

\begin{tabular}{|c|c|c|c|c|c|c|c|c|c|c|c|c|c|c|c|c|}
\hline \multicolumn{17}{|c|}{ Panel A. NLSY Men Born After 1961} \\
\hline \multirow[t]{2}{*}{ Year } & \multicolumn{2}{|c|}{1990} & \multicolumn{2}{|c|}{1991} & \multicolumn{2}{|c|}{1992} & \multicolumn{2}{|c|}{1993} & \multicolumn{2}{|c|}{1994} & \multicolumn{2}{|c|}{1996} & \multicolumn{2}{|c|}{1998} & \multicolumn{2}{|c|}{2000} \\
\hline & I & II & I & II & I & II & I & II & I & II & I & II & I & II & I & II \\
\hline Black & $\begin{array}{l}-0.250 \\
(0.028)\end{array}$ & $\begin{array}{c}-0.060 \\
(0.030)\end{array}$ & $\begin{array}{l}-0.251 \\
(0.028)\end{array}$ & $\begin{array}{l}-0.082 \\
(0.030)\end{array}$ & $\begin{array}{l}-0.302 \\
(0.029)\end{array}$ & $\begin{array}{l}-0.113 \\
(0.030)\end{array}$ & $\begin{array}{l}-0.282 \\
(0.028)\end{array}$ & $\begin{array}{c}-0.104 \\
(0.030)\end{array}$ & $\begin{array}{l}-0.286 \\
(0.031)\end{array}$ & $\begin{array}{l}-0.093 \\
(0.033)\end{array}$ & $\begin{array}{l}-0.373 \\
(0.032)\end{array}$ & $\begin{array}{l}-0.149 \\
(0.034)\end{array}$ & $\begin{array}{l}-0.333 \\
(0.034)\end{array}$ & $\begin{array}{l}-0.069 \\
(0.035)\end{array}$ & $\begin{array}{l}-0.325 \\
(0.035)\end{array}$ & $\begin{array}{l}-0.089 \\
(0.035)\end{array}$ \\
\hline Hispanic & $\begin{array}{l}-0.174 \\
(0.032)\end{array}$ & $\begin{array}{l}-0.035 \\
(0.032)\end{array}$ & $\begin{array}{l}-0.113 \\
(0.032)\end{array}$ & $\begin{array}{c}0.020 \\
(0.033)\end{array}$ & $\begin{array}{l}-0.146 \\
(0.033)\end{array}$ & $\begin{array}{l}-0.014 \\
(0.032)\end{array}$ & $\begin{array}{l}-0.159 \\
(0.032)\end{array}$ & $\begin{array}{l}-0.027 \\
(0.032)\end{array}$ & $\begin{array}{l}-0.143 \\
(0.036)\end{array}$ & $\begin{array}{c}0.005 \\
(0.036)\end{array}$ & $\begin{array}{l}-0.186 \\
(0.038)\end{array}$ & $\begin{array}{l}-0.031 \\
(0.038)\end{array}$ & $\begin{array}{l}-0.195 \\
(0.040)\end{array}$ & $\begin{array}{l}-0.006 \\
(0.038)\end{array}$ & $\begin{array}{l}-0.215 \\
(0.040)\end{array}$ & $\begin{array}{l}-0.053 \\
(0.038)\end{array}$ \\
\hline Age & $\begin{array}{l}- \\
-\end{array}$ & $\begin{array}{c}0.050 \\
(0.014)\end{array}$ & $\begin{array}{l}- \\
-\end{array}$ & $\begin{array}{c}0.030 \\
(0.014)\end{array}$ & $\begin{array}{l}- \\
-\end{array}$ & $\begin{array}{c}0.038 \\
(0.014)\end{array}$ & - & $\begin{array}{c}0.030 \\
(0.014)\end{array}$ & - & $\begin{array}{c}0.023 \\
(0.016)\end{array}$ & $\begin{array}{l}- \\
-\end{array}$ & $\begin{array}{c}0.020 \\
(0.016)\end{array}$ & - & $\begin{array}{c}0.014 \\
(0.017)\end{array}$ & - & $\begin{array}{c}0.008 \\
(0.017)\end{array}$ \\
\hline AFQT & - & $\begin{array}{c}0.183 \\
(0.013)\end{array}$ & - & $\begin{array}{c}0.161 \\
(0.013)\end{array}$ & - & $\begin{array}{c}0.179 \\
(0.013)\end{array}$ & - & $\begin{array}{c}0.172 \\
(0.013)\end{array}$ & - & $\begin{array}{c}0.188 \\
(0.014)\end{array}$ & - & $\begin{array}{c}0.216 \\
(0.015)\end{array}$ & - & $\begin{array}{c}0.254 \\
(0.015)\end{array}$ & - & $\begin{array}{c}0.241 \\
(0.015)\end{array}$ \\
\hline $\mathrm{AFQT}^{2}$ & - & $\begin{array}{l}-0.022 \\
(0.011)\end{array}$ & - & $\begin{array}{l}-0.007 \\
(0.011)\end{array}$ & - & $\begin{array}{l}-0.001 \\
(0.011)\end{array}$ & - & $\begin{array}{c}0.002 \\
(0.011)\end{array}$ & - & $\begin{array}{c}0.014 \\
(0.012)\end{array}$ & - & $\begin{array}{c}0.021 \\
(0.013)\end{array}$ & - & $\begin{array}{c}0.032 \\
(0.013)\end{array}$ & - & $\begin{array}{c}0.023 \\
(0.013)\end{array}$ \\
\hline Intercept & $\begin{array}{r}2.375 \\
(0.017) \\
\end{array}$ & $\begin{array}{c}0.957 \\
(0.385) \\
\end{array}$ & $\begin{array}{c}2.372 \\
(0.017)\end{array}$ & $\begin{array}{c}1.463 \\
(0.406) \\
\end{array}$ & $\begin{array}{c}2.404 \\
(0.017)\end{array}$ & $\begin{array}{c}1.202 \\
(0.422)\end{array}$ & $\begin{array}{c}2.423 \\
(0.017)\end{array}$ & $\begin{array}{c}1.431 \\
(0.432) \\
\end{array}$ & $\begin{array}{c}2.458 \\
(0.018) \\
\end{array}$ & $\begin{array}{c}1.652 \\
(0.488) \\
\end{array}$ & $\begin{array}{c}2.533 \\
(0.019) \\
\end{array}$ & $\begin{array}{c}1.756 \\
(0.540) \\
\end{array}$ & $\begin{array}{r}2.589 \\
(0.020) \\
\end{array}$ & $\begin{array}{c}1.960 \\
(0.594)\end{array}$ & $\begin{array}{c}2.629 \\
(0.020) \\
\end{array}$ & $\begin{array}{c}2.224 \\
(0.621) \\
\end{array}$ \\
\hline $\mathrm{N}$ & 1538 & 1505 & 1553 & 1514 & 1536 & 1503 & 1542 & 1504 & 1522 & 1485 & 1554 & 1519 & 1494 & 1462 & 1438 & 1404 \\
\hline \multicolumn{17}{|c|}{ Panel B. NLSY Women Born After 1961} \\
\hline \multirow[t]{2}{*}{ Year: } & \multicolumn{2}{|c|}{1990} & \multicolumn{2}{|c|}{ 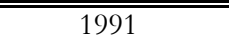 } & \multicolumn{2}{|c|}{1992} & \multicolumn{2}{|c|}{1993} & \multicolumn{2}{|c|}{1994} & \multicolumn{2}{|c|}{1996} & \multicolumn{2}{|c|}{1998} & \multicolumn{2}{|c|}{2000} \\
\hline & I & II & $\mathrm{I}$ & II & I & II & I & II & $\mathrm{I}$ & II & I & II & I & II & I & II \\
\hline Black & $\begin{array}{c}-0.172 \\
(0.031)\end{array}$ & $\begin{array}{c}0.041 \\
(0.033)\end{array}$ & $\begin{array}{l}-0.200 \\
(0.032)\end{array}$ & $\begin{array}{c}0.030 \\
(0.035)\end{array}$ & $\begin{array}{l}-0.201 \\
(0.031)\end{array}$ & $\begin{array}{c}0.010 \\
(0.033)\end{array}$ & $\begin{array}{l}-0.167 \\
(0.035)\end{array}$ & $\begin{array}{c}0.093 \\
(0.037)\end{array}$ & $\begin{array}{l}-0.148 \\
(0.035)\end{array}$ & $\begin{array}{c}0.099 \\
(0.037)\end{array}$ & $\begin{array}{l}-0.147 \\
(0.035)\end{array}$ & $\begin{array}{c}0.132 \\
(0.036)\end{array}$ & $\begin{array}{l}-0.201 \\
(0.034)\end{array}$ & $\begin{array}{c}0.071 \\
(0.036)\end{array}$ & $\begin{array}{c}-0.200 \\
(0.036)\end{array}$ & $\begin{array}{c}0.069 \\
(0.038)\end{array}$ \\
\hline Hispanic & $\begin{array}{l}-0.003 \\
(0.035)\end{array}$ & $\begin{array}{c}0.154 \\
(0.035)\end{array}$ & $\begin{array}{l}-0.017 \\
(0.037)\end{array}$ & $\begin{array}{c}0.153 \\
(0.038)\end{array}$ & $\begin{array}{l}-0.059 \\
(0.036)\end{array}$ & $\begin{array}{c}0.114 \\
(0.035)\end{array}$ & $\begin{array}{c}0.009 \\
(0.039)\end{array}$ & $\begin{array}{c}0.198 \\
(0.039)\end{array}$ & $\begin{array}{l}-0.018 \\
(0.040)\end{array}$ & $\begin{array}{c}0.170 \\
(0.040)\end{array}$ & $\begin{array}{l}-0.006 \\
(0.041)\end{array}$ & $\begin{array}{c}0.193 \\
(0.039)\end{array}$ & $\begin{array}{l}-0.069 \\
(0.039)\end{array}$ & $\begin{array}{c}0.151 \\
(0.039)\end{array}$ & $\begin{array}{l}-0.064 \\
(0.041)\end{array}$ & $\begin{array}{c}0.149 \\
(0.041)\end{array}$ \\
\hline Age & - & $\begin{array}{c}0.010 \\
(0.015)\end{array}$ & - & $\begin{array}{c}0.038 \\
(0.017)\end{array}$ & - & $\begin{array}{c}0.016 \\
(0.016)\end{array}$ & - & $\begin{array}{c}0.016 \\
(0.017)\end{array}$ & - & $\begin{array}{c}0.008 \\
(0.018)\end{array}$ & - & $\begin{array}{l}-0.009 \\
(0.018)\end{array}$ & - & $\begin{array}{c}0.013 \\
(0.017)\end{array}$ & $\begin{array}{l}- \\
-\end{array}$ & $\begin{array}{l}-0.018 \\
(0.018)\end{array}$ \\
\hline AFQT & - & $\begin{array}{c}0.217 \\
(0.016)\end{array}$ & - & $\begin{array}{c}0.234 \\
(0.018)\end{array}$ & - & $\begin{array}{c}0.229 \\
(0.017)\end{array}$ & - & $\begin{array}{c}0.271 \\
(0.018)\end{array}$ & - & $\begin{array}{c}0.267 \\
(0.019)\end{array}$ & - & $\begin{array}{c}0.283 \\
(0.018)\end{array}$ & - & $\begin{array}{c}0.274 \\
(0.018)\end{array}$ & - & $\begin{array}{c}0.273 \\
(0.018)\end{array}$ \\
\hline $\mathrm{AFQT}^{2}$ & - & $\begin{array}{c}0.005 \\
(0.014)\end{array}$ & - & $\begin{array}{c}0.000 \\
(0.014)\end{array}$ & - & $\begin{array}{l}-0.001 \\
(0.014)\end{array}$ & - & $\begin{array}{l}-0.012 \\
(0.015)\end{array}$ & $\begin{array}{l}- \\
-\end{array}$ & $\begin{array}{l}-0.024 \\
(0.016)\end{array}$ & - & $\begin{array}{c}0.005 \\
(0.015)\end{array}$ & - & $\begin{array}{c}0.000 \\
(0.015)\end{array}$ & $\begin{array}{l}- \\
-\end{array}$ & $\begin{array}{l}-0.008 \\
(0.015)\end{array}$ \\
\hline Intercept & $\begin{array}{c}2.141 \\
(0.019)\end{array}$ & $\begin{array}{c}1.750 \\
(0.420)\end{array}$ & $\begin{array}{c}2.175 \\
(0.020)\end{array}$ & $\begin{array}{c}0.982 \\
(0.467)\end{array}$ & $\begin{array}{c}2.193 \\
(0.019)\end{array}$ & $\begin{array}{c}1.615 \\
(0.458)\end{array}$ & $\begin{array}{c}2.174 \\
(0.021)\end{array}$ & $\begin{array}{c}1.558 \\
(0.520)\end{array}$ & $\begin{array}{c}2.218 \\
(0.022)\end{array}$ & $\begin{array}{c}1.858 \\
(0.555)\end{array}$ & $\begin{array}{c}2.246 \\
(0.022) \\
\end{array}$ & $\begin{array}{c}2.412 \\
(0.582)\end{array}$ & $\begin{array}{c}2.311 \\
(0.021)\end{array}$ & $\begin{array}{c}1.724 \\
(0.603)\end{array}$ & $\begin{array}{c}2.339 \\
(0.022) \\
\end{array}$ & $\begin{array}{c}2.867 \\
(0.663) \\
\end{array}$ \\
\hline $\mathrm{N}$ & 1356 & 1325 & 1335 & 1299 & 1317 & 1278 & 1319 & 1281 & 1318 & 1288 & 1381 & 1344 & 1370 & 1329 & 1316 & 1276 \\
\hline
\end{tabular}

Age-corrected AFQT is the standardized residual from the regression of the AFQT score on age at the time of the test dummy variables. AFQT is a subset of 4 out of 10 ASVAB tests used by the military for enlistment screening and job assignment. It is the summed score from the word knowledge, paragraph comprehension, mathematics knowledge, and arithmetic reasoning ASVAB tests. All wages are in 1993 dollars. The coefficients on the AFQT variables represent the effect of a one standard deviation increase in the score on the log hourly wage. Since the wage is measured in log points, the gaps for blacks and hispanics correspond approximately to percentage point differences relative to the white mean; that is, the black-white gap of -.25 in 1990 corresponds to $25 \%$ lower wages for blacks in that year. 


\section{Figure 1A \\ Density of Age-Corrected AFQT \\ NLSY79 Males Born After 1961}

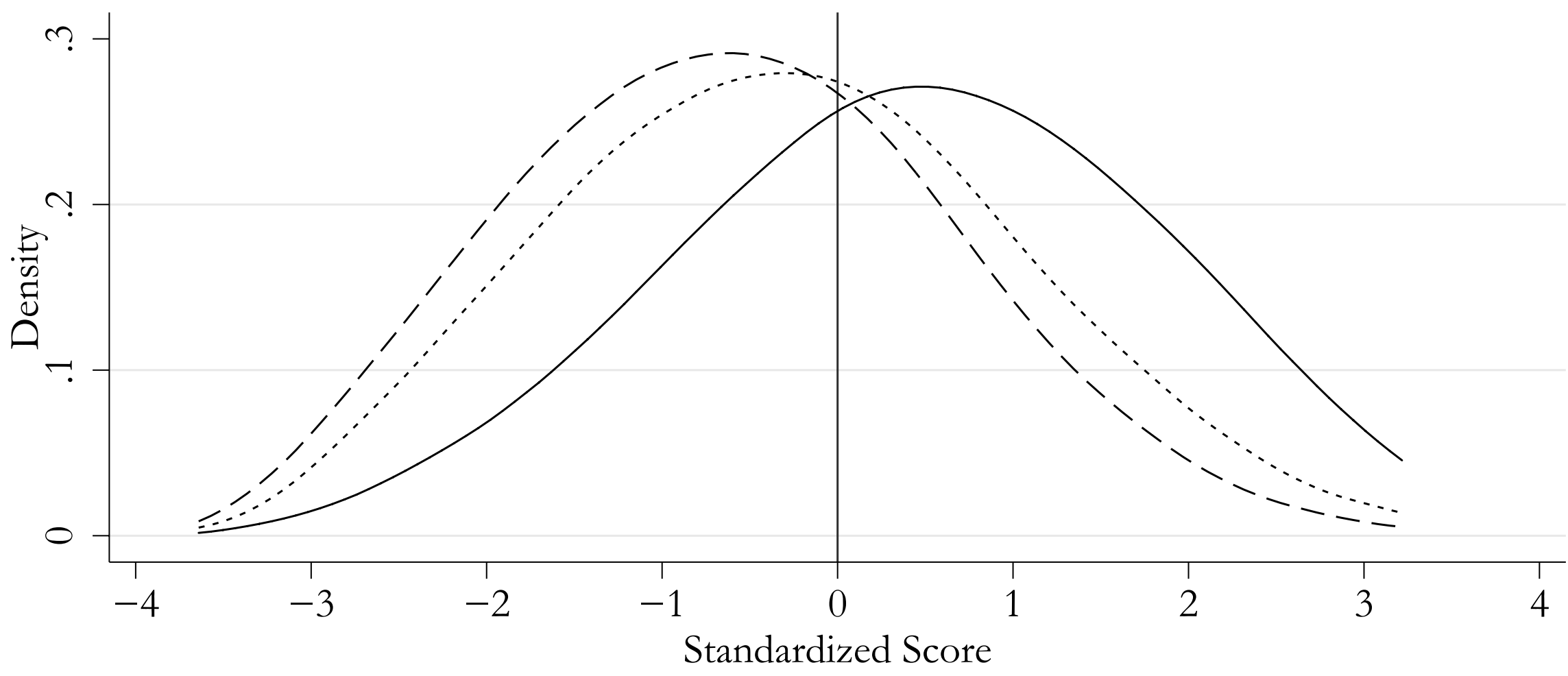

White - - - - Black ......... Hispanic

Age-corrected AFQT is the standardized residual from the regression of the AFQT score on age at the time of the test dummy variables. AFQT is a subset of 4 out of 10 ASVAB tests used by the military for enlistment screening and job assignment. It is the summed score from the word knowledge, paragraph comprehension, mathematics knowledge, and arithmetic reasoning ASVAB tests. 


\section{Figure 1B \\ Density of Age-Corrected AFQT}

NLSY79 Females Born After 1961

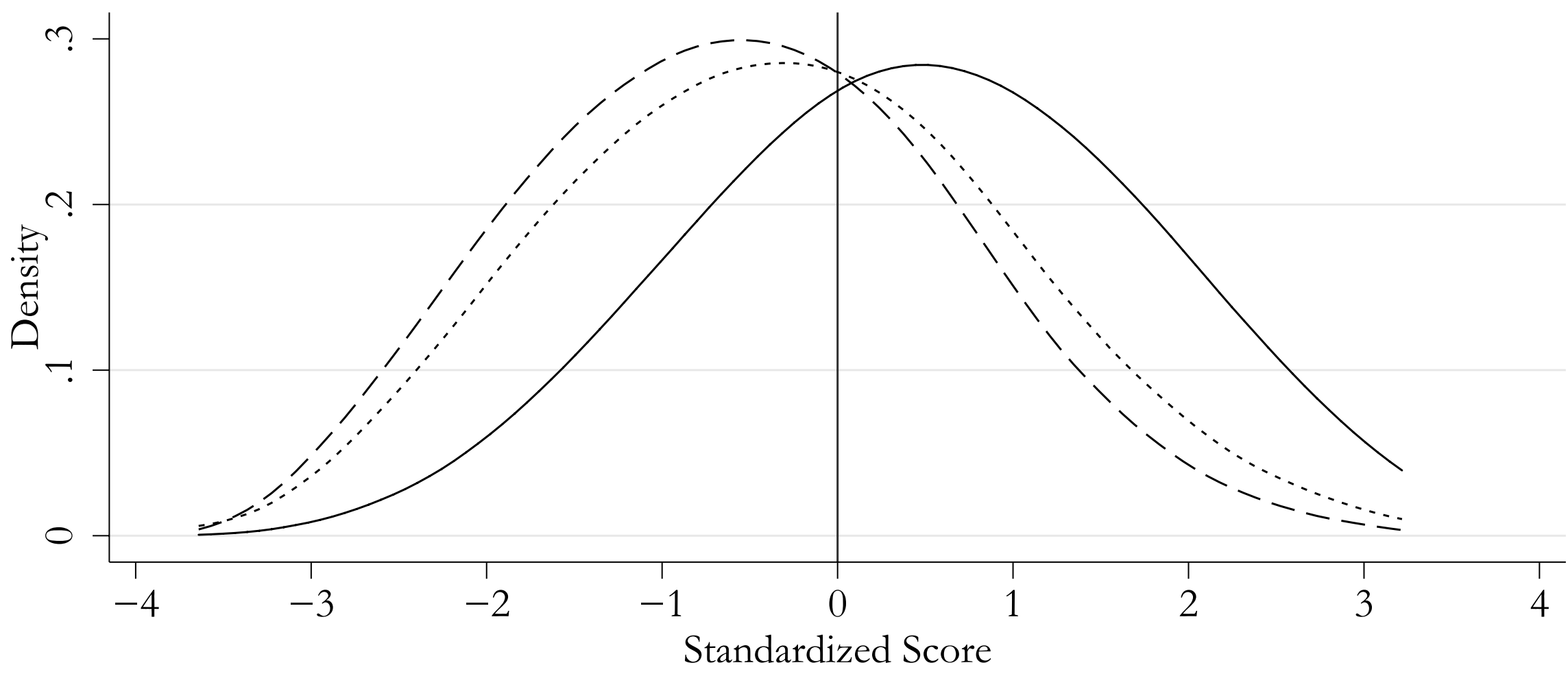

$$
\text { White - - - Black ......... Hispanic }
$$

Age-corrected AFQT is the standardized residual from the regression of the AFQT score on age at the time of the test dummy variables. AFQT is a subset of 4 out of 10 ASVAB tests used by the military for enlistment screening and job assignment. It is the summed score from the word knowledge, paragraph comprehension, mathematics knowledge, and arithmetic reasoning ASVAB tests. 


\section{Figure 2A \\ Percentile PIAT Math Score By Race and Age Group}

\section{Children of NLSY79 Males}

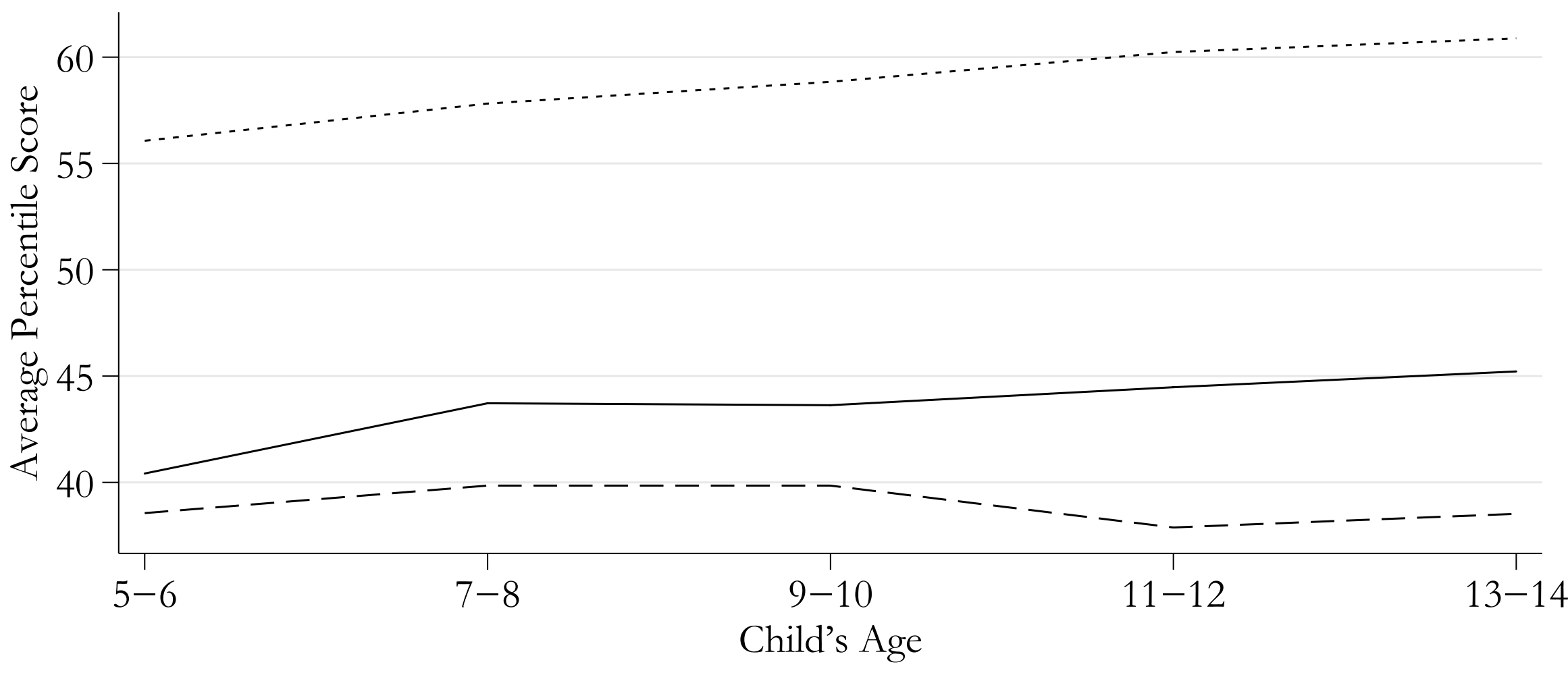

— Hispanic - - - - Black ……... White

This test measures the child's attainment in mathematics as taught in mainstream education. It consists of 84 multiple-choice questions of increasing difficulty, beginning with recognizing numerals and progressing to geometry and trigonometry. The percentile score was calculated separately for each sex at each age. span 


\section{Figure 2B \\ Percentile PIAT Math Score By Race and Age Group}

Children of NLSY79 Females

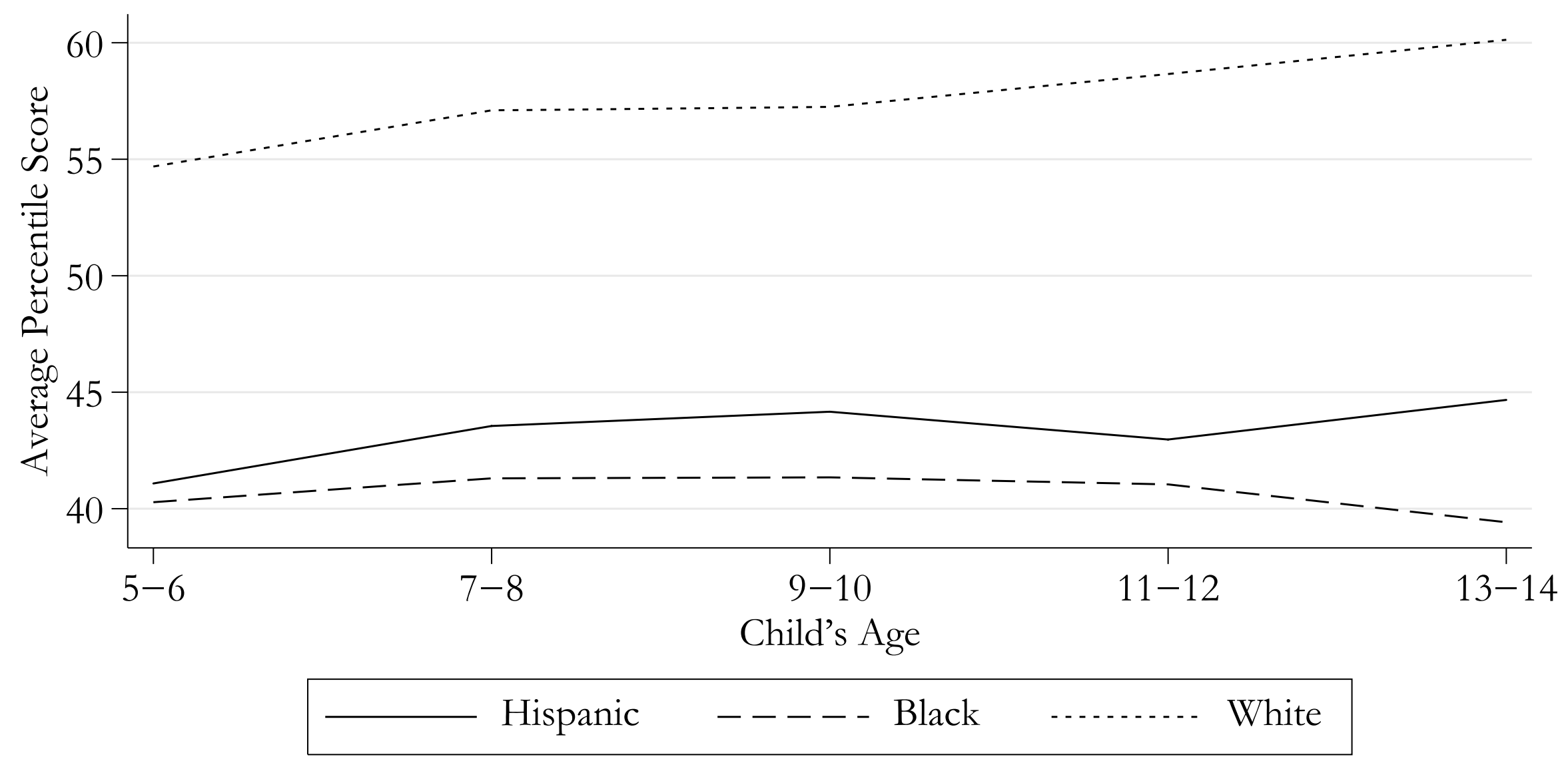

This test measures the child's attainment in mathematics as taught in mainstream education. It consists of 84 multiple-choice questions of increasing difficulty, beginning with recognizing numerals and progressing to geometry and trigonometry. The percentile score was calculated separately for each sex at each age. span 


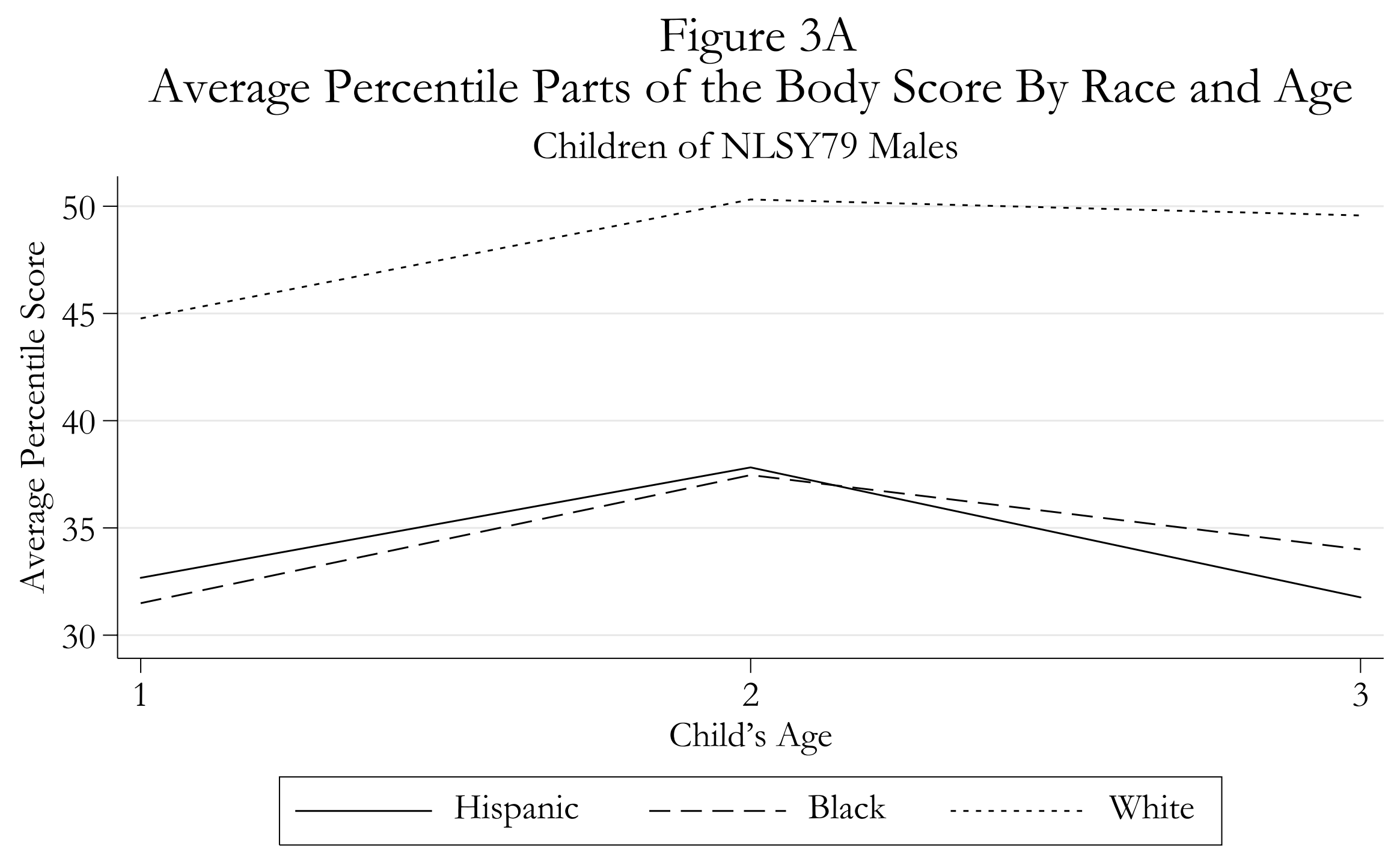

This test attempts to measure the young child's receptive vocabulary knowledge of orally presented words as a means of estimating intellectual development. The interviewer names each of ten body parts and asks the child to point to that part of the body. The score is computed by summing the number of correct responses. The percentile score was calculated separately for each sex at each age. 


\section{Figure 3B Average Percentile Parts of the Body Score By Race and Age Children of NLSY79 Females}

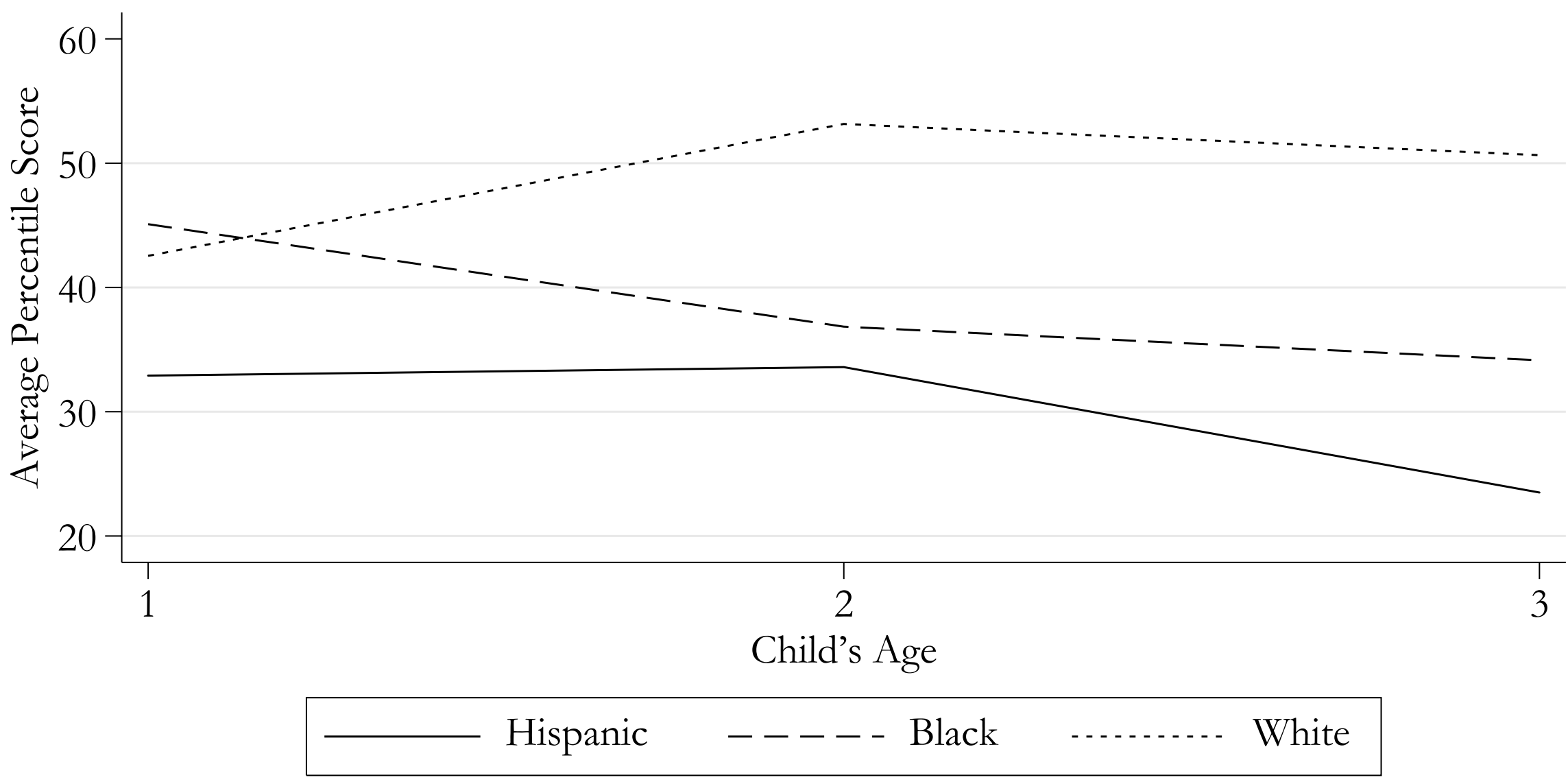

This test attempts to measure the young child's receptive vocabulary knowledge of orally presented words as a means of estimating intellectual development. The interviewer names each of ten body parts and asks the child to point to that part of the body. The score is computed by summing the number of correct responses. The percentile score was calculated separately for each sex at each age. 


\section{Figure 4A \\ Density of Percentile PIAT Math Scores at Ages 5-6 \\ CNLSY 79 Males}

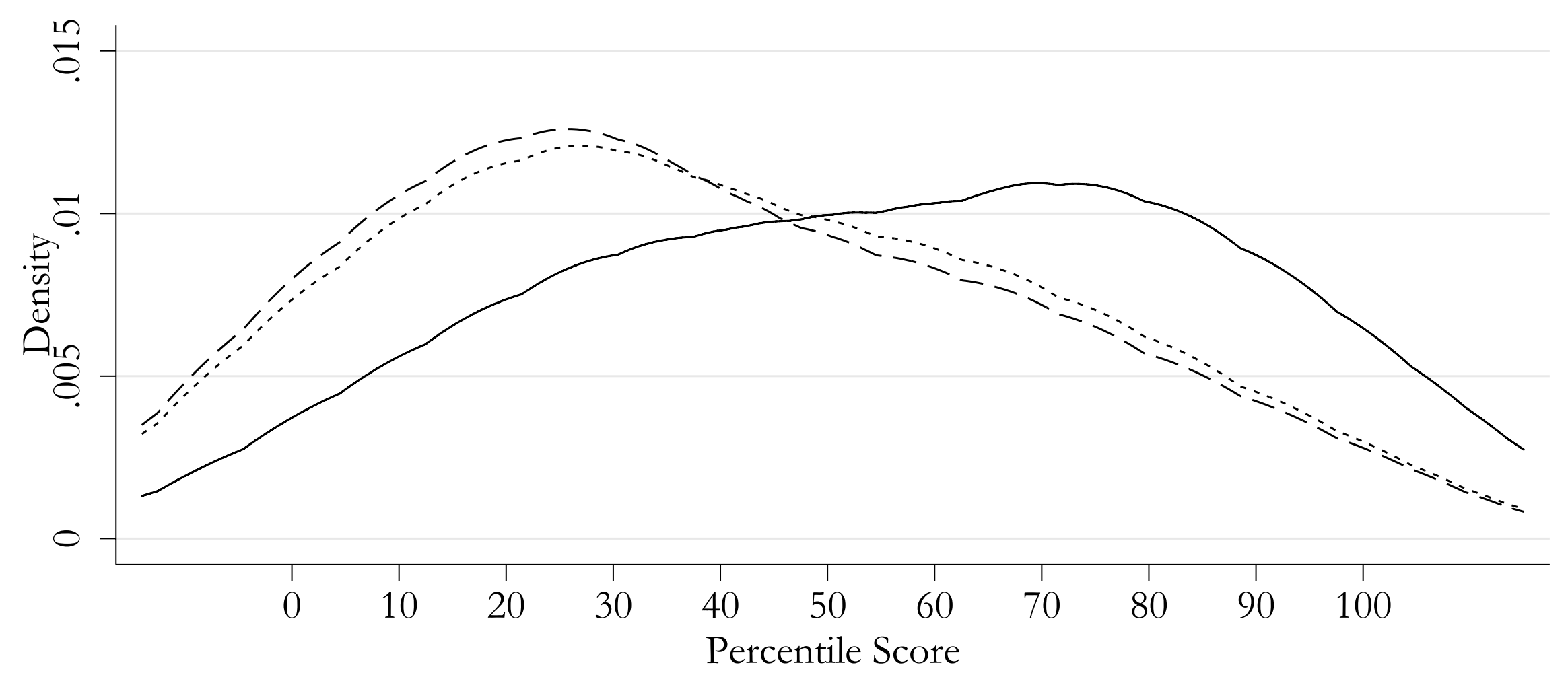

White - - - - Black .......... Hispanic

This test measures the child's attainment in mathematics as taught in mainstream education. It consists of 84 multiple-choice questions of increasing difficulty, beginning with recognizing numerals and progressing to geometry and trigonometry. The percentile score was calculated separately for each sex at each age. 


\section{Figure 4B \\ Density of Percentile PIAT Math Scores at Ages 5-6 \\ CNLSY 79 Females}

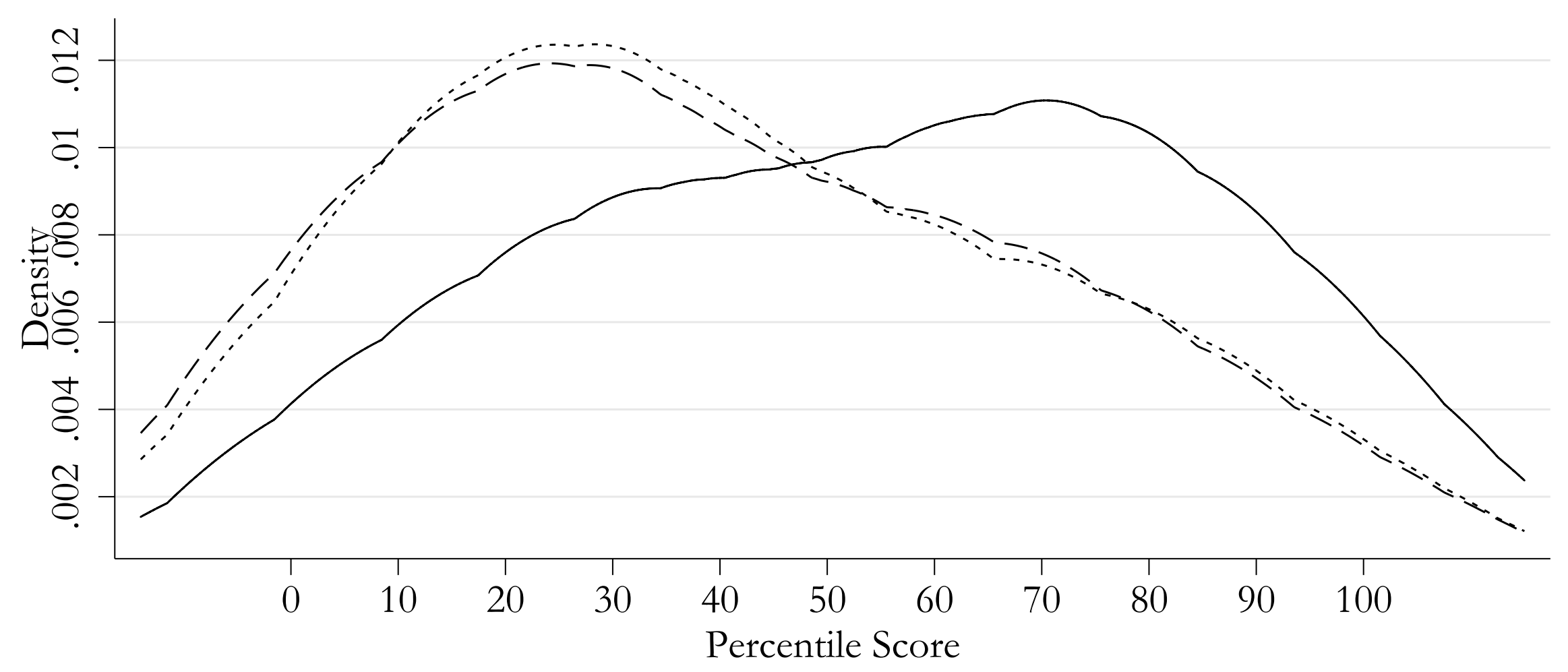

White ----- Black …...... Hispanic

This test measures the child's attainment in mathematics as taught in mainstream education. It consists of 84 multiple-choice questions of increasing difficulty, beginning with recognizing numerals and progressing to geometry and trigonometry. The percentile score was calculated separately for each sex at each age. 


\section{Figure $5 \mathrm{~A}$ \\ Adjusted Percentile PIAT Math Score By Race and Age Group}

\section{Children of NLSY79 Males}

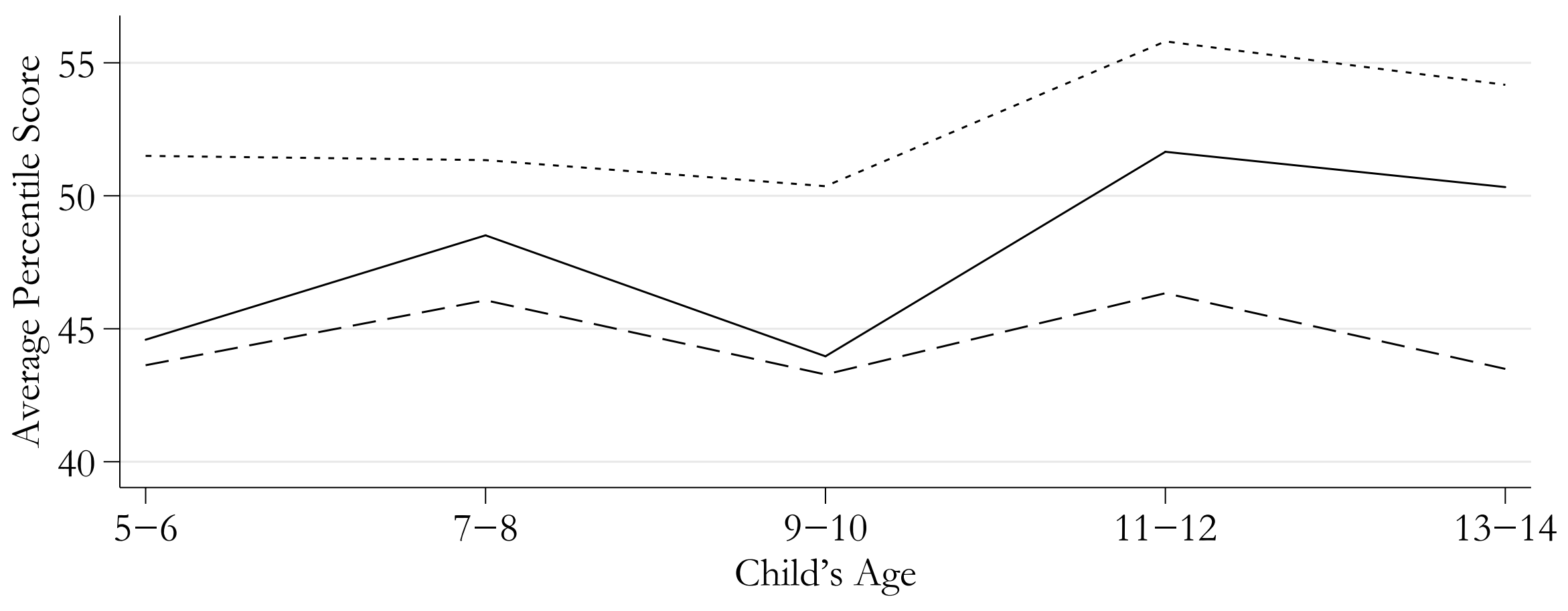

\section{Hispanic - - - - Black …....... White}

Adjusted by permanent family income, mother's education and age-corrected AFQT, and home score.

Adjusted indicates that we equalized the family background characteristics across all race groups by setting them at the mean to purge the effect of family environment disparities. Permanent income is constructed by taking the average of annual family income discounted to child's age 0 using a 10\% discount rate. Age-corrected AFQT is the standardized residual from the regression of the AFQT score on age at the time of the test dummy variables. Home score is an index of quality of the child's home environment. 


\section{Figure 5B \\ Adjusted Percentile PIAT Math Score By Race and Age Group}

\section{Children of NLSY79 Females}

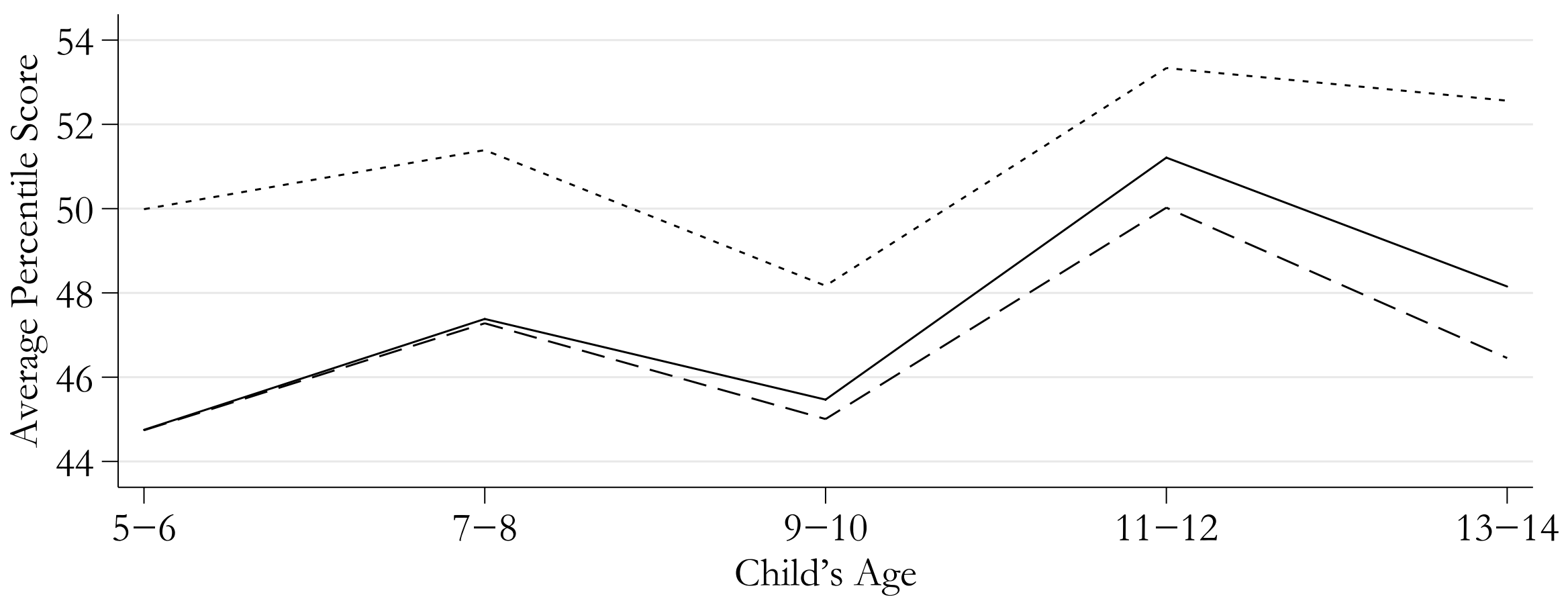

\section{Hispanic - - - - Black …...... White}

Adjusted by permanent family income, mother's education and age-corrected AFQT, and home score.

Adjusted indicates that we equalized the family background characteristics across all race groups by setting them at the mean to purge the effect of family environment disparities. Permanent income is constructed by taking the average of annual family income discounted to child's age 0 using a 10\% discount rate. Age-corrected AFQT is the standardized residual from the regression of the AFQT score on age at the time of the test dummy variables. Home score is an index of quality of the child's home environment. 


\section{Figure 6 \\ Density of Log Permanent Income}

CNLSY 79 Males and Females

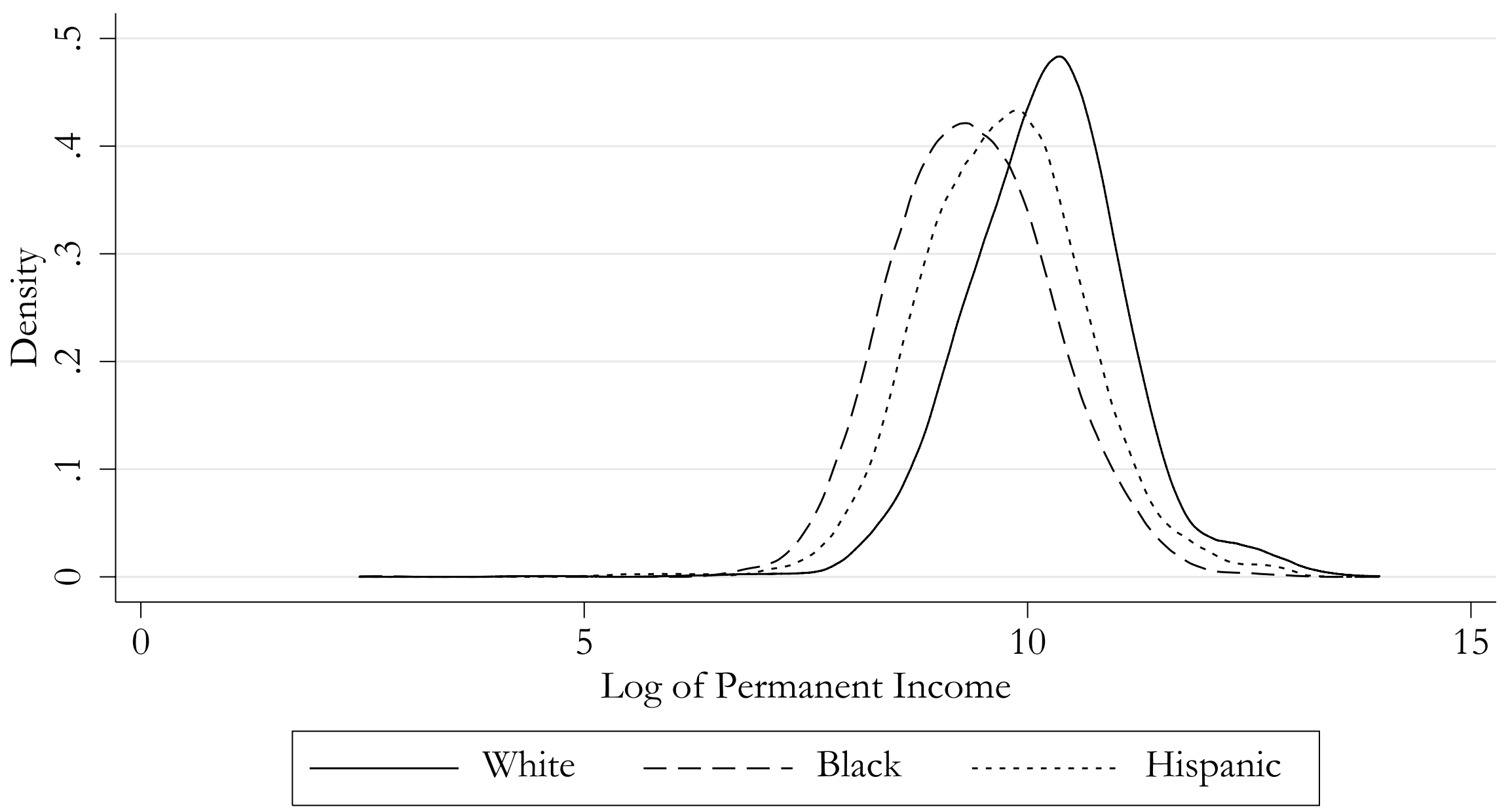

Permanent income is constructed by taking the average of annual family income discounted to child's age 0 using a 10\% discount rate. 
Figure 7

Density of Mother's Highest Grade Completed

CNLSY79 Males and Females

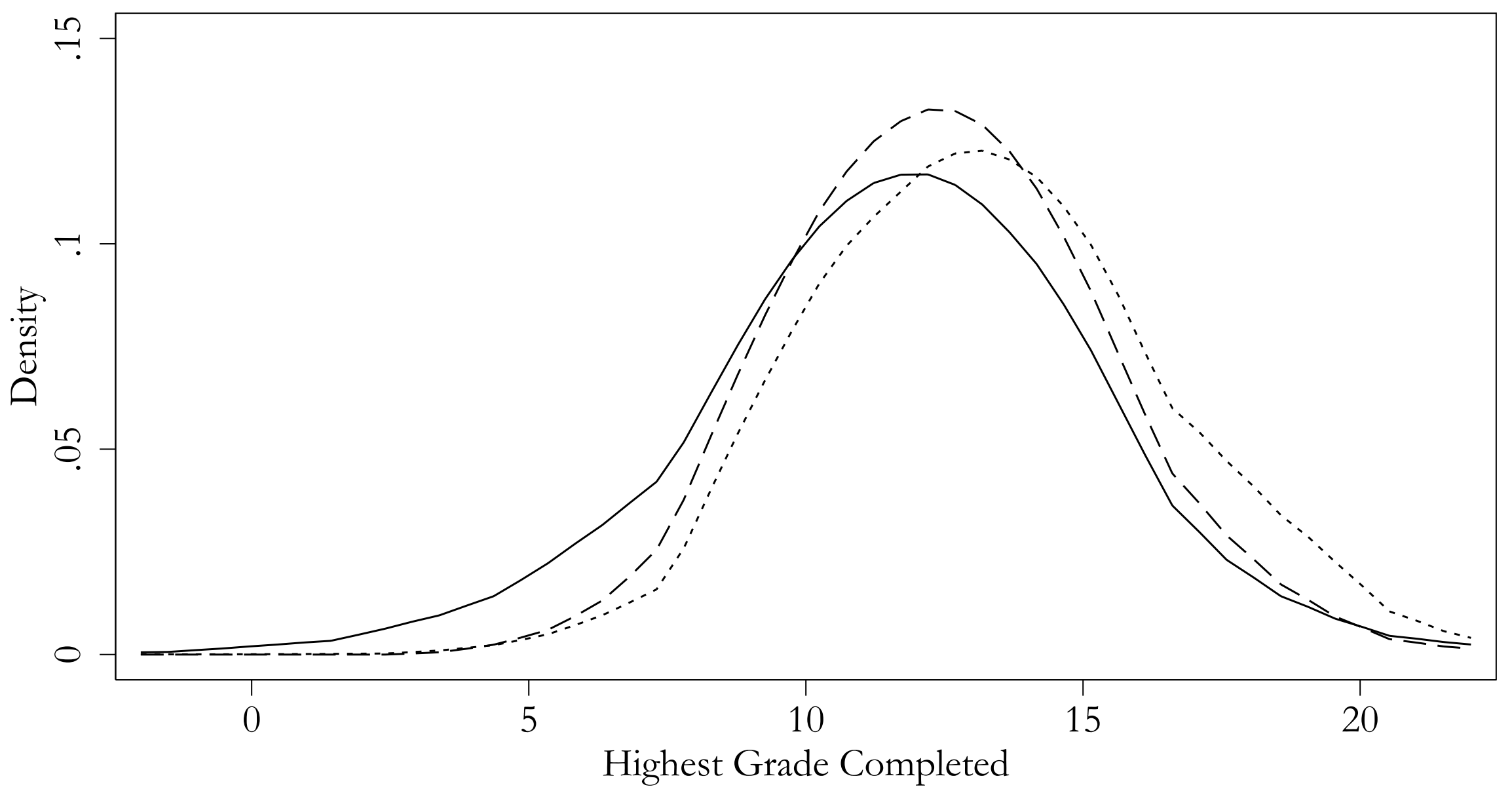

Hispanic - - - - Black

White 


\section{Figure 8 \\ Density of Mother's Age-Corrected AFQT}

\section{CNLSY79 Males and Females}

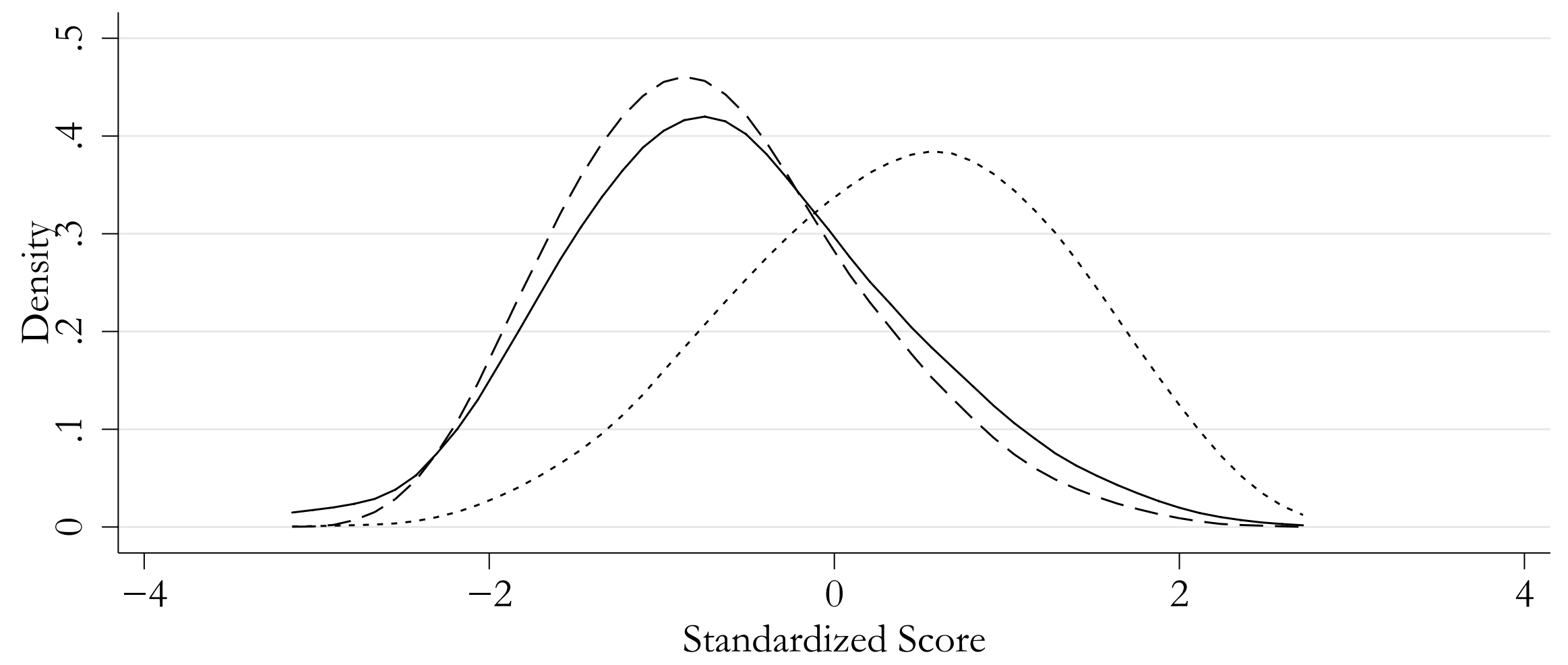

- Hispanic - - - Black .......... White

Age-corrected AFQT is the standardized residual from the regression of the AFQT score on age at the time of the test dummy variables. AFQT is a subset of 4 out of 10 ASVAB tests used by the military for enlistment screening and job assignment. It is the summed score from the word knowledge, paragraph comprehension, mathematics knowledge, and arithmetic reasoning ASVAB tests. 
Figure 9

\section{How Often Mother Reads to Child at Age 2 by Race and Sex}

CNLSY79
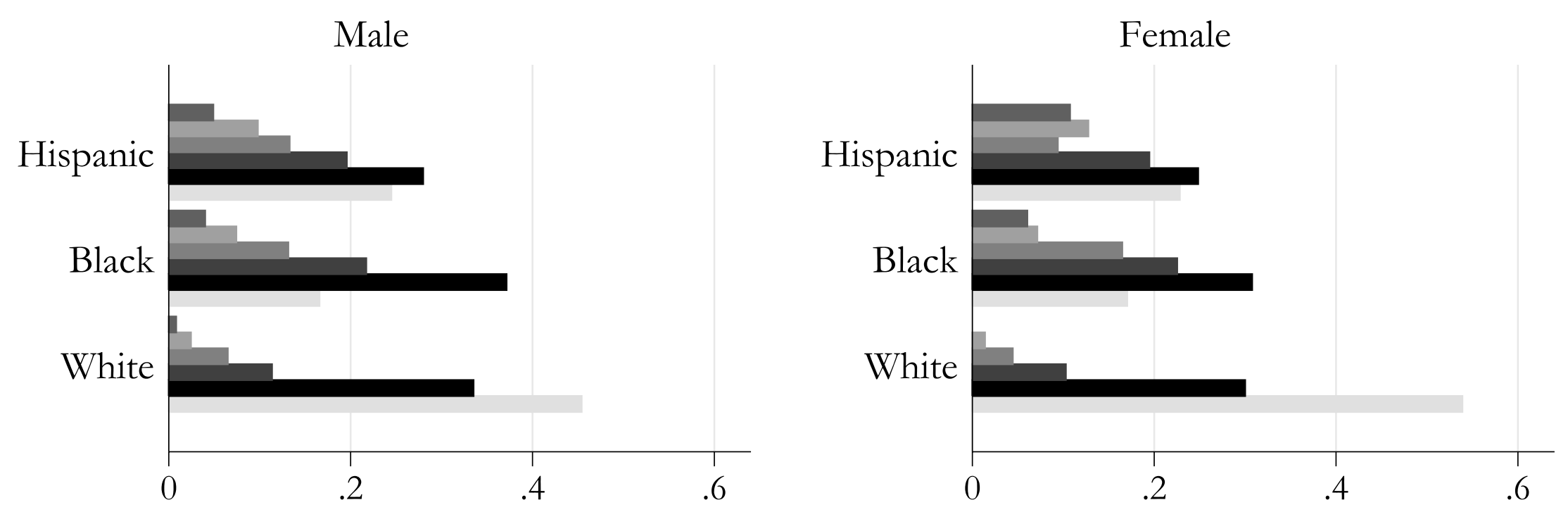

Fraction

\begin{tabular}{|l|l|}
\hline Never & Several Times a Year \\
Several Times a Month & Once A Week \\
About 3 Times a Week & Every Day \\
\hline
\end{tabular}

The height of the bar is produced by dividing the number of people who report falling in a particular reading frequency cell by the total number of people in their race-sex group 


\section{Figure 10 \\ Density of Home Score \\ CNLSY79 Males and Females}

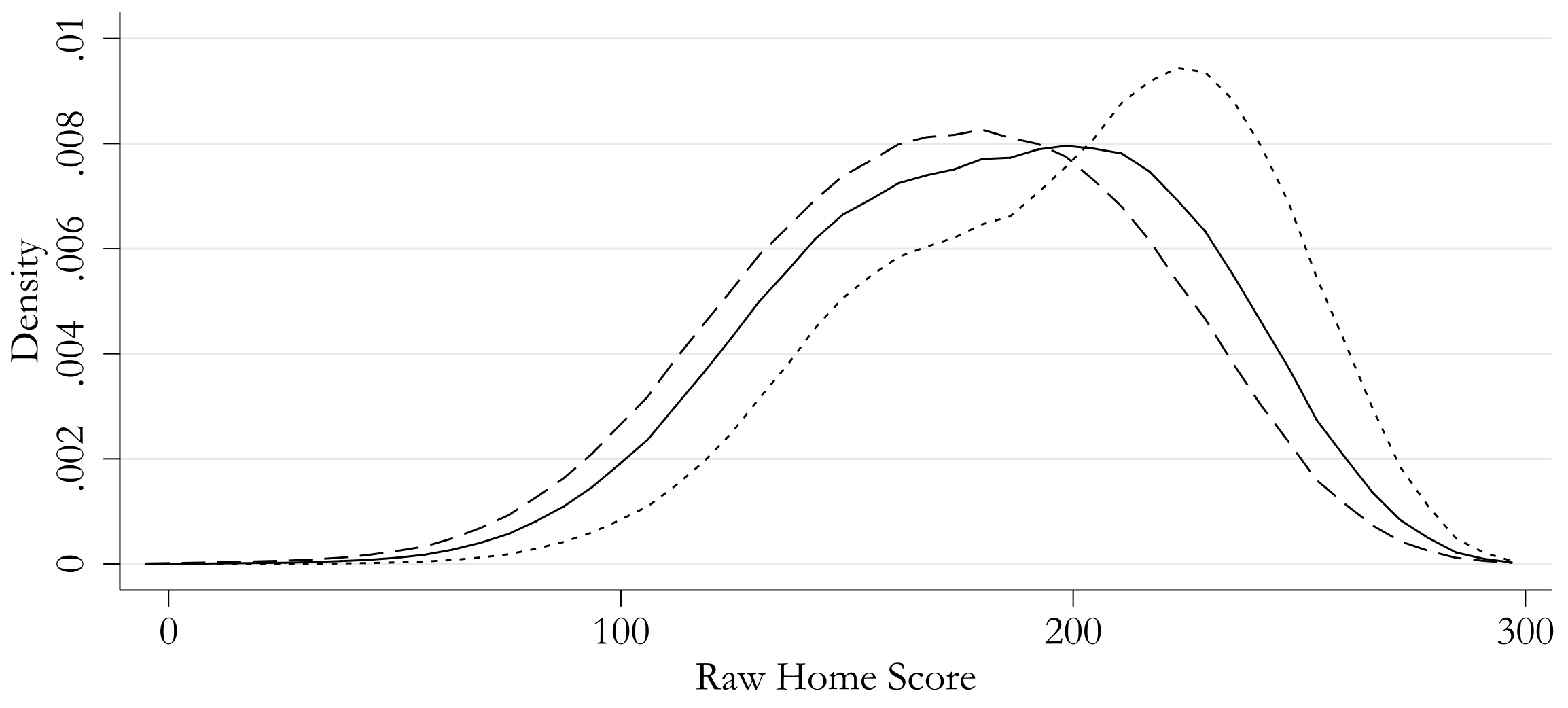

- Hispanic $\quad-----$ Black .......... White

Home Score is an index of the quality of a child's home environment included in CNLSY79.

It consists of various measures of age-specific cognitive and emotional stimulation based

on dichotomized and summed responses to mother's self-report and interviewer observation. 
Figure 11

Fraction of Children Who Live in a Broken Home by Age and Race CNLSY79 Males and Females

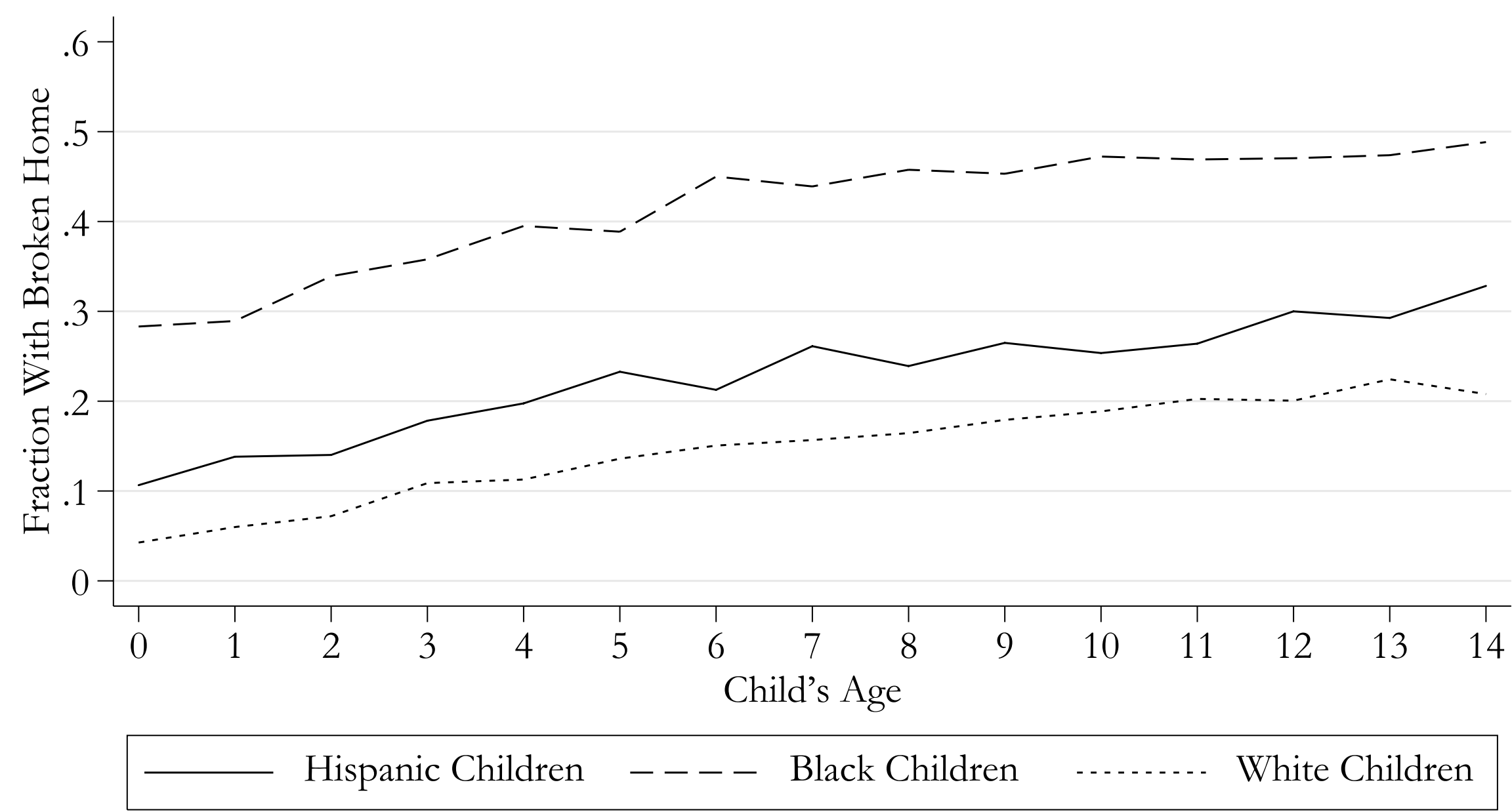

Note: We define a child living in a broken home as a child not living in a household with two biological parents, or living with the mother and her common law partner 
Figure 12

\section{Highest Category of Schooling Completed at Test Date by Race, Sex and Age \\ NLSY79 Born After 1961}
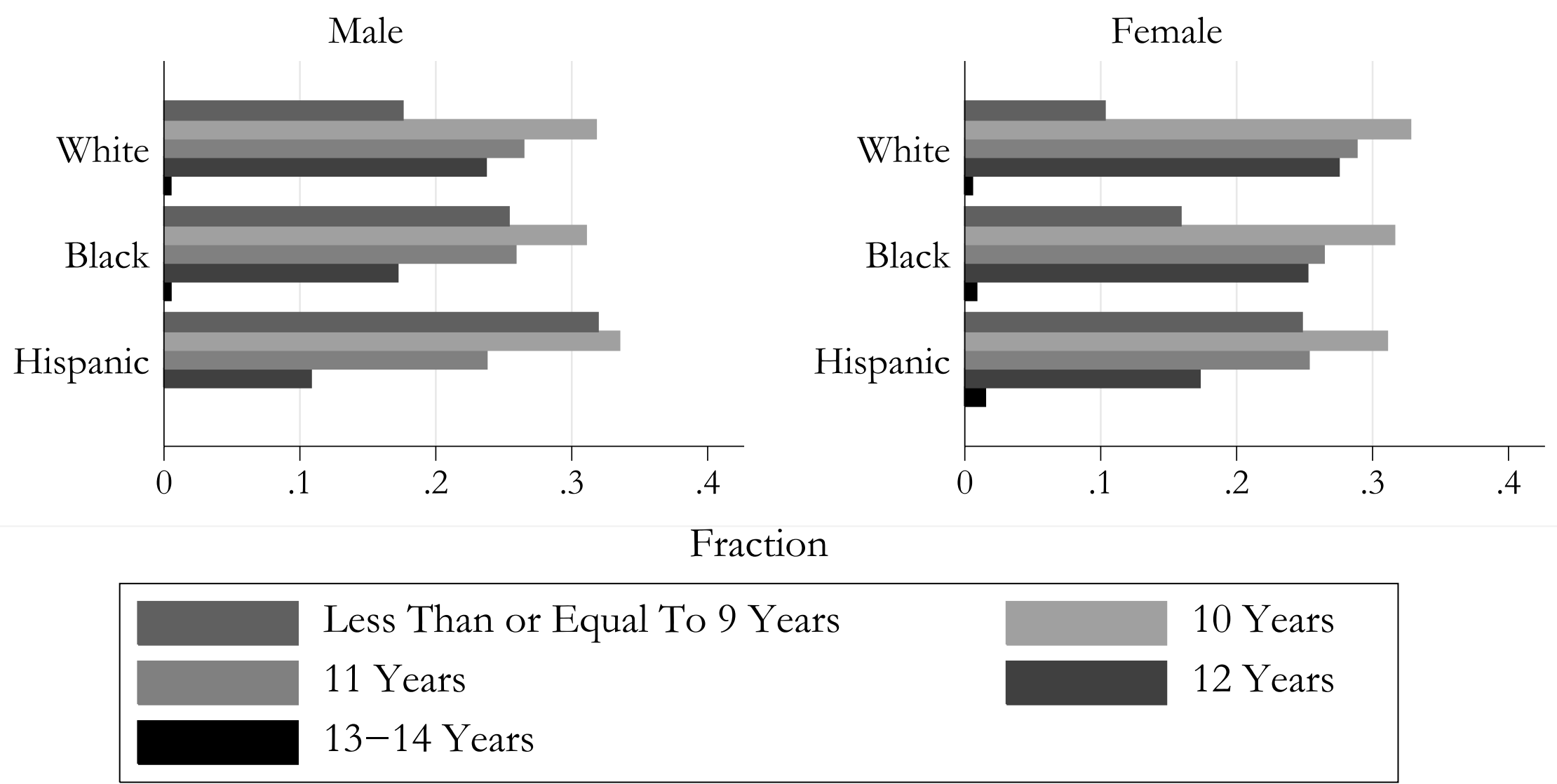

The height of the bar is produced by dividing the number of people who report falling in a particular education cell by the total number of people in their race-sex group 
Table 2

AFQT and Schooling NLSY79

\begin{tabular}{|c|c|c|c|c|c|c|}
\hline \multicolumn{7}{|c|}{ Panel A. Effect of Schooling on Raw AFQT ${ }^{\mathrm{a}}$} \\
\hline \multirow[b]{2}{*}{ Schooling At Test Date } & \multicolumn{2}{|c|}{ White } & \multicolumn{2}{|c|}{ Black } & \multicolumn{2}{|c|}{ Hispanic } \\
\hline & Male & Female & Male & Female & Male & Female \\
\hline 9 & 12.68 & 14.66 & 5.21 & 5.95 & 9.80 & 11.22 \\
\hline Std. Err. & $(1.51)$ & $(1.70)$ & $(1.58)$ & $(1.74)$ & $(1.90)$ & $(1.79)$ \\
\hline $\mathrm{N}$ & 378 & 343 & 234 & 234 & 167 & 179 \\
\hline 10 & 16.94 & 16.12 & 9.22 & 5.65 & 16.33 & 14.99 \\
\hline Std. Err. & $(1.52)$ & $(1.68)$ & $(1.53)$ & $(1.73)$ & $(1.94)$ & $(1.85)$ \\
\hline $\mathrm{N}$ & 377 & 368 & 282 & 237 & 161 & 169 \\
\hline$\overline{11}$ & 22.02 & 18.55 & 8.87 & 10.62 & 18.67 & 16.83 \\
\hline Std. Err. & $(1.54)$ & $(1.72)$ & $(1.58)$ & $(1.75)$ & $(2.11)$ & $(2.01)$ \\
\hline $\mathrm{N}$ & 366 & 327 & 247 & 243 & 120 & 122 \\
\hline$\overline{12}$ & 23.12 & 21.05 & 11.96 & 11.12 & 21.29 & 16.46 \\
\hline Std. Err. & $(1.49)$ & $(1.64)$ & $(1.58)$ & $(1.70)$ & $(2.08)$ & $(1.95)$ \\
\hline $\mathrm{N}$ & 630 & 758 & 322 & 393 & 171 & 198 \\
\hline $13-15$ & 26.60 & 24.37 & 15.37 & 14.23 & 23.96 & 18.92 \\
\hline Std. Err. & $(1.73)$ & $(1.83)$ & $(2.23)$ & $(2.00)$ & $(2.82)$ & $(2.55)$ \\
\hline $\mathrm{N}$ & 266 & 326 & 98 & 180 & 72 & 81 \\
\hline 16 or More & 29.02 & 25.71 & 28.43 & 22.66 & 33.11 & 31.18 \\
\hline Std. Err. & $(2.13)$ & $(2.24)$ & $(3.56)$ & $(2.99)$ & $(4.70)$ & $(4.03)$ \\
\hline $\mathrm{N}$ & 108 & 103 & 27 & 34 & 17 & 22 \\
\hline \multicolumn{7}{|c|}{ Panel B. Mean Schooling-Corrected AFQT For Those With 8 Years of Schooling } \\
\hline Mean & 52.50 & 51.95 & 36.79 & 37.44 & 38.45 & 36.87 \\
\hline Std. Dev & $(19.11)$ & $(17.81)$ & $(17.76)$ & $(16.15)$ & $(19.17)$ & $(17.80)$ \\
\hline $\mathrm{N}$ & 165 & 110 & 172 & 98 & 154 & 137 \\
\hline
\end{tabular}


Table 3

Change in the Black-White Log Wage Gap Induced by Controlling for Schooling-Corrected AFQT for 1990-2001 NLSY Men born after 1961

\begin{tabular}{|c|c|c|c|c|c|c|c|c|c|c|c|c|c|c|c|c|}
\hline \multirow[t]{2}{*}{ Year } & \multicolumn{2}{|c|}{19990} & \multicolumn{2}{|c|}{1991} & \multicolumn{2}{|c|}{1992} & \multicolumn{2}{|c|}{191993} & \multicolumn{2}{|c|}{1994} & \multicolumn{2}{|c|}{1996} & \multicolumn{2}{|c|}{1998} & \multicolumn{2}{|c|}{2000} \\
\hline & I & II & I & II & I & II & I & II & I & II & I & II & I & II & I & II \\
\hline \multirow[t]{2}{*}{ Black } & -0.250 & -0.133 & -0.251 & -0.149 & -0.302 & -0.180 & -0.282 & -0.171 & -0.286 & -0.165 & -0.373 & -0.230 & -0.333 & -0.160 & -0.325 & -0.172 \\
\hline & $(0.028)$ & $(0.029)$ & $(0.028)$ & $(0.029)$ & $(0.029)$ & $(0.029)$ & $(0.028)$ & $(0.029)$ & (0.031) & $(0.031)$ & $(0.032)$ & $(0.032)$ & (0.034) & $(0.034)$ & $(0.035)$ & $(0.033)$ \\
\hline Hispanic & $(0.032)$ & $(0.032)$ & $(0.032)$ & $(0.032)$ & $(0.033)$ & $(0.032)$ & $(0.032)$ & $(0.032)$ & $(0.036)$ & $(0.036)$ & $(0.038)$ & $(0.038)$ & $(0.040)$ & $(0.038)$ & $(0.040)$ & $(0.038)$ \\
\hline \multirow[t]{2}{*}{ Age } & - & 0.065 & - & 0.043 & - & 0.055 & - & 0.045 & - & 0.040 & - & 0.039 & - & 0.036 & - & 0.029 \\
\hline & - & $(0.014)$ & - & (0.015) & - & (0.015) & - & $(0.015)$ & - & $(0.016)$ & - & $(0.017)$ & - & $(0.017)$ & - & $(0.017)$ \\
\hline \multirow[t]{2}{*}{ AFQT } & - & 0.153 & - & 0.131 & - & 0.155 & - & 0.144 & - & 0.159 & - & 0.184 & - & 0.221 & - & 0.211 \\
\hline & - & $(0.013)$ & - & $(0.013)$ & - & (0.013) & - & $(0.013)$ & - & $(0.014)$ & - & $(0.015)$ & - & $(0.015)$ & - & $(0.015)$ \\
\hline \multirow[t]{2}{*}{$\mathrm{AFQT}^{2}$} & - & 0.001 & - & 0.009 & - & 0.015 & - & 0.017 & - & 0.028 & - & 0.031 & - & 0.040 & - & 0.036 \\
\hline & - & $(0.010)$ & - & $(0.010)$ & - & $(0.010)$ & - & $(0.010)$ & - & $(0.011)$ & - & $(0.012)$ & - & $(0.012)$ & - & $(0.012)$ \\
\hline \multirow[t]{2}{*}{ Constant } & 2.375 & 0.540 & 2.372 & 1.085 & 2.404 & 0.732 & 2.423 & 0.982 & 2.458 & 1.119 & 2.533 & 1.140 & 2.589 & 1.172 & 2.629 & 1.425 \\
\hline & $(0.017)$ & $(0.392)$ & $(0.017)$ & $(0.412)$ & $(0.017)$ & $(0.426)$ & $(0.017)$ & $(0.437)$ & $(0.018)$ & $(0.493)$ & $(0.019)$ & $(0.547)$ & $(0.020)$ & $(0.603)$ & $(0.020)$ & $(0.628)$ \\
\hline $\mathrm{N}$ & 1538 & 1505 & 1553 & 1514 & 1536 & 1503 & 1542 & 1504 & 1522 & 1485 & 1554 & 1519 & 1494 & 1462 & 1438 & 1404 \\
\hline \multicolumn{17}{|c|}{ NLSY Women born after 1961} \\
\hline Year & \multicolumn{2}{|c|}{ "1990 } & \multicolumn{2}{|c|}{1991} & \multicolumn{2}{|c|}{1992} & \multicolumn{2}{|c|}{1993} & \multicolumn{2}{|c|}{19994} & \multicolumn{2}{|c|}{19996} & \multicolumn{2}{|c|}{1998} & \multicolumn{2}{|c|}{2000} \\
\hline Black & -0.172 & -0.045 & -0.200 & -0.066 & -0.201 & -0.083 & -0.167 & -0.020 & -0.148 & -0.014 & -0.147 & 0.025 & -0.201 & -0.043 & -0.200 & -0.041 \\
\hline & $(0.031)$ & $(0.031)$ & $(0.032)$ & $(0.033)$ & $(0.031)$ & $(0.031)$ & $(0.035)$ & $(0.035)$ & $(0.035)$ & $(0.035)$ & $(0.035)$ & $(0.034)$ & (0.034) & $(0.034)$ & $(0.036)$ & $(0.035)$ \\
\hline Hispanic & -0.003 & 0.116 & -0.017 & 0.107 & -0.059 & 0.069 & 0.009 & 0.145 & -0.018 & 0.119 & -0.006 & 0.149 & -0.069 & 0.098 & -0.064 & 0.096 \\
\hline & $(0.035)$ & $(0.035)$ & $(0.037)$ & $(0.037)$ & $(0.036)$ & $(0.035)$ & $(0.039)$ & $(0.039)$ & $(0.040)$ & $(0.040)$ & $(0.041)$ & $(0.039)$ & $(0.039)$ & $(0.038)$ & $(0.041)$ & $(0.040)$ \\
\hline Age & - & 0.015 & - & 0.042 & - & 0.021 & - & 0.024 & - & 0.015 & - & -0.003 & - & 0.019 & - & -0.010 \\
\hline & - & $(0.016)$ & - & $(0.017)$ & - & $(0.016)$ & - & $(0.018)$ & - & $(0.018)$ & - & (0.018) & - & $(0.017)$ & - & $(0.018)$ \\
\hline AFQT & - & 0.188 & - & 0.197 & - & 0.187 & - & 0.221 & - & 0.221 & - & 0.245 & - & 0.228 & - & 0.235 \\
\hline & - & $(0.016)$ & - & $(0.017)$ & - & (0.016) & - & $(0.018)$ & - & $(0.018)$ & - & (0.018) & - & $(0.017)$ & - & (0.018) \\
\hline AFQT $^{2}$ & - & 0.010 & - & 0.009 & - & 0.010 & - & 0.006 & - & -0.008 & - & 0.022 & - & 0.017 & - & 0.005 \\
\hline & - & $(0.013)$ & - & $(0.014)$ & - & (0.013) & - & $(0.015)$ & - & $(0.015)$ & - & $(0.015)$ & - & $(0.015)$ & - & $(0.015)$ \\
\hline Constant & 2.141 & 1.633 & 2.175 & 0.893 & 2.193 & 1.488 & 2.174 & 1.337 & 2.218 & 1.662 & 2.246 & 2.228 & 2.311 & 1.550 & 2.339 & 2.608 \\
\hline & $(0.019)$ & $(0.424)$ & $(0.020)$ & $(0.472)$ & $(0.019)$ & $(0.465)$ & $(0.021)$ & $(0.530)$ & $(0.022)$ & $(0.565)$ & $(0.022)$ & $(0.588)$ & $(0.021)$ & $(0.612)$ & $(0.022)$ & $(0.671)$ \\
\hline $\mathrm{N}$ & 1356 & 1325 & 1335 & 1299 & 1317 & 1278 & 1319 & 1281 & 1318 & 1287 & 1381 & 1343 & 1370 & 1328 & 1316 & 1276 \\
\hline
\end{tabular}

schooling completed during lifetime. AFQT is a subset of 4 out of 10 ASVAB tests used by the military for enlistment screening and job assignment. It is the summed score from the word knowledge, paragraph comprehension, mathematics knowledge, and arithmetic reasoning ASVAB tests. All wages are in 1993 dollars. 
Figure 13A

Residual Black-White Log Wage Gap in 1991 By Grade

At Which We Evaluate The School-Corrected AFQT

NLSY79 Males Born After 1961

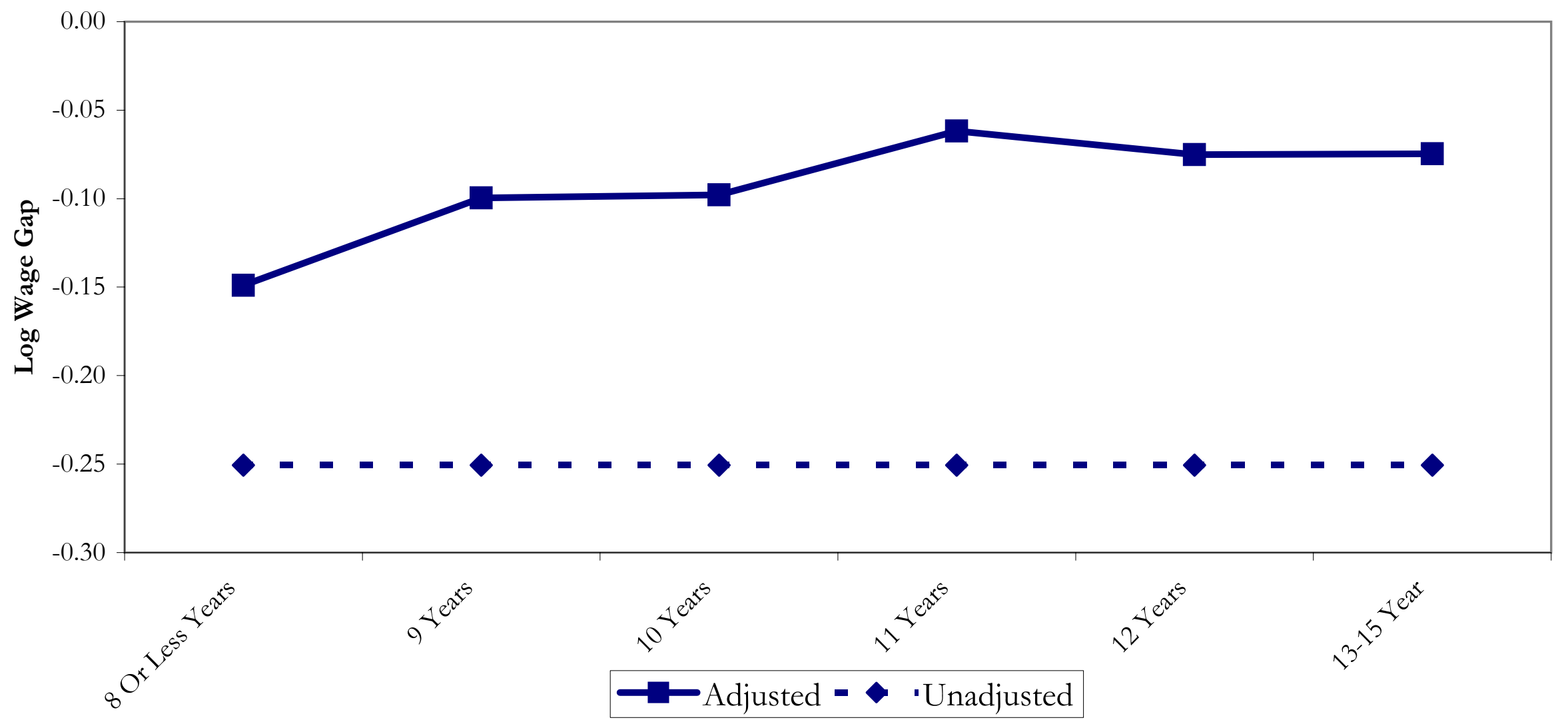

Grade At Which We Evaluate the Schooling-Corrected AFQT

Note: We have omitted the results for the "16 or More" category because the low number of minorities in that cell make the correction of the test scores to that schooling level much less reliable than the correction to the other schooling levels. The "unadjusted" line refers to the black-white log wage gap we observe if we do not control for AFQT scores (column I in table 1). Therefore it is a horizontal line since it does not depend on the grade to which we are correcting the test score. The "adjusted" line refers to the black-white log wage gap we observe after we adjust for the AFQT scores corrected to different grades. 


\section{Figure 13B}

\section{Residual Hispanic-White Log Wage Gap in 1991 By Grade \\ At Which We Evaluate The School-Corrected AFQT \\ NLSY79 Males Born After 1961}

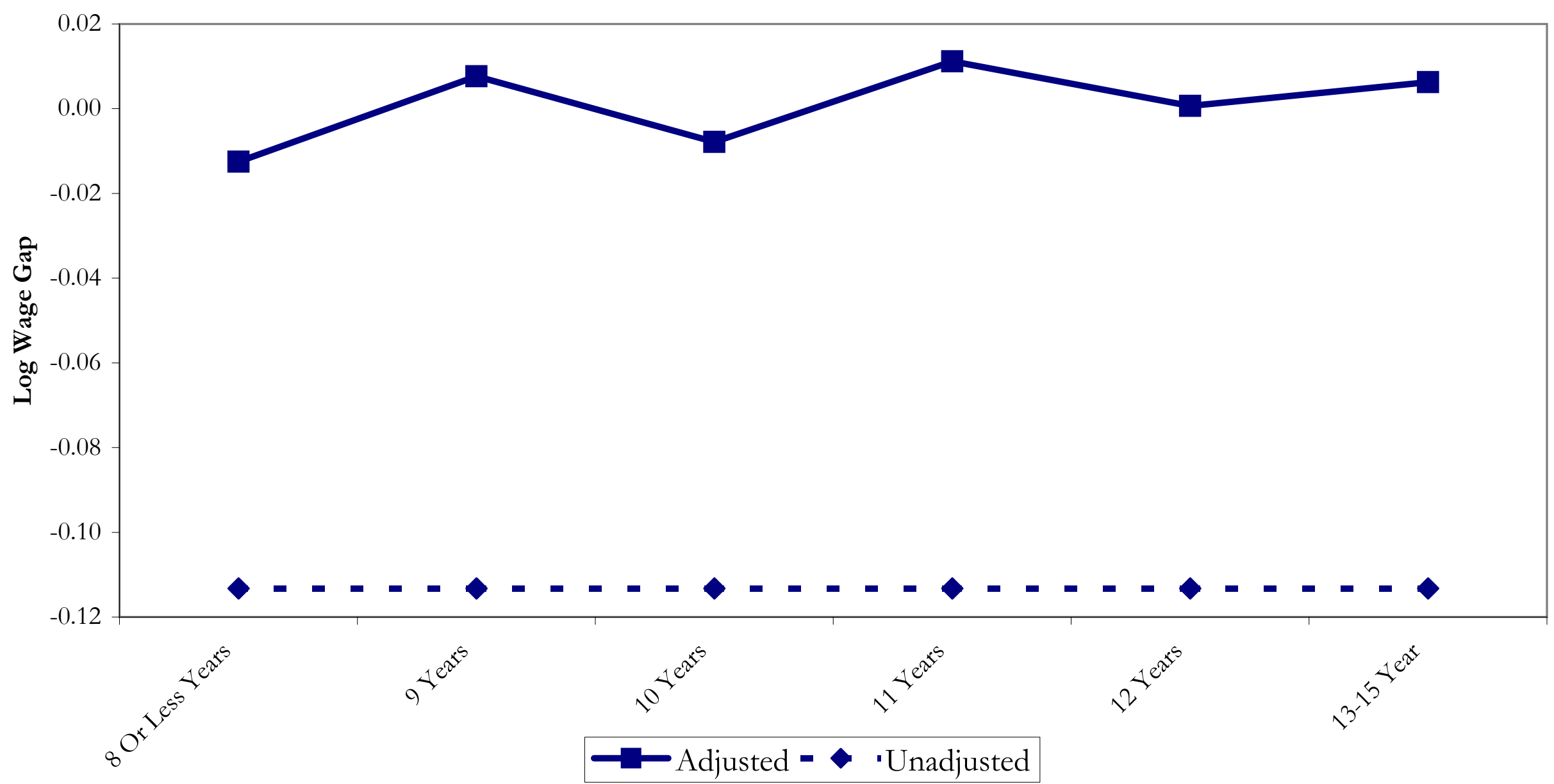

Grade At Which We Evaluate the Schooling-Corrected AFQT

Note: We have omitted the results for the "16 or More" category because the low number of minorities in that cell make the correction of the test scores to that schooling level much less reliable than the correction to the other schooling levels. The "unadjusted" line refers to the Hispanic-white log wage gap we observe if we do not control for AFQT scores (column I in table 1). Therefore it is a horizontal line since it does not depend on the grade to which we are correcting the test score. The "adjusted" line refers to the Hispanic-white log wage gap we observe after we adjust for the AFQT scores corrected to different grades. 
Figure 13C

\section{Residual Black-White Log Wage Gap For 1991 By Grade \\ At Which We Evaluate The School-Corrected AFQT \\ NLSY79 Females Born After 1961}

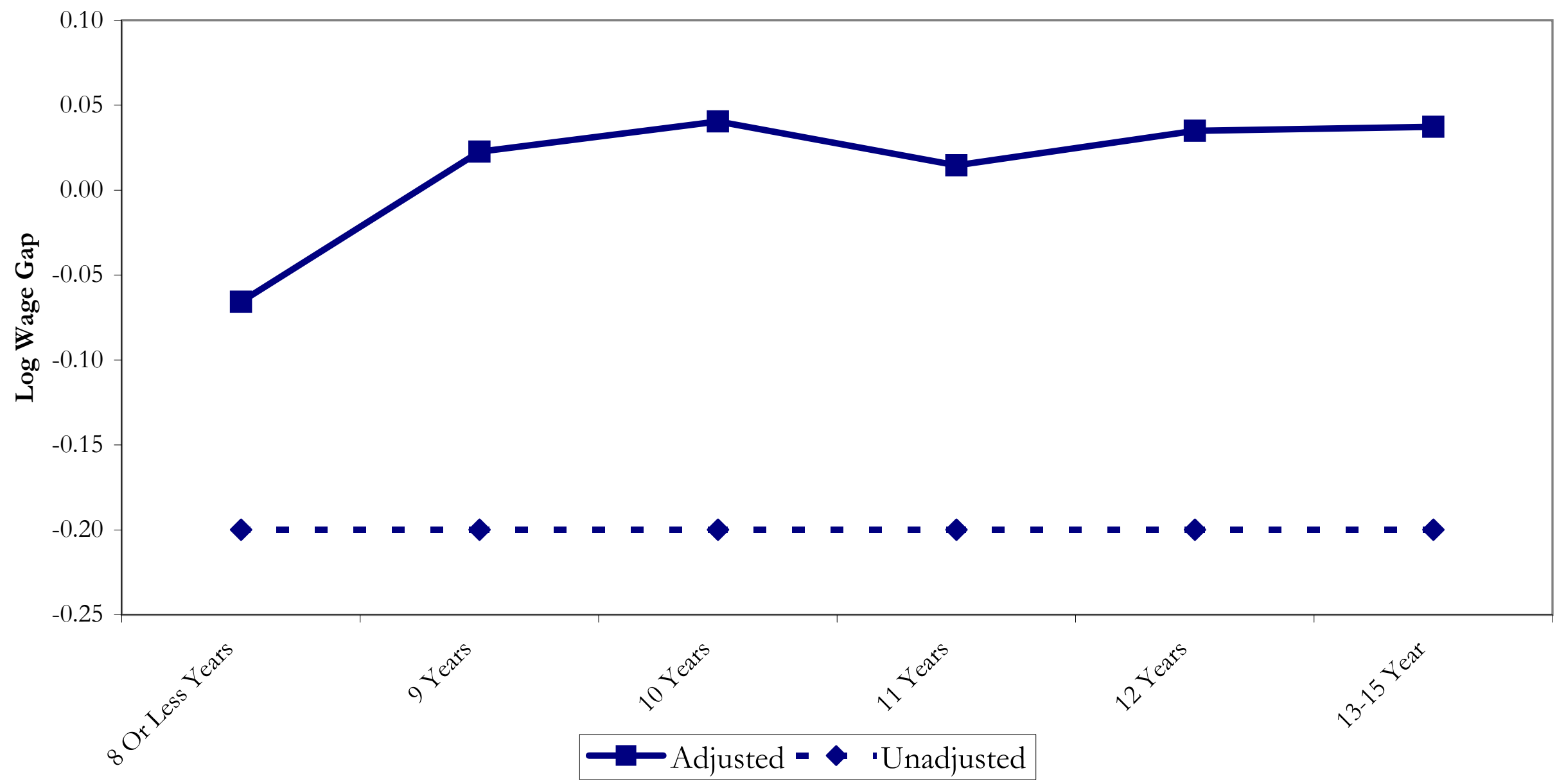

Grade At Which We Evaluate the Schooling-Corrected AFQT

Note: We have omitted the results for the "16 or More" category because the low number of minorities in that cell make the correction of the test scores to that schooling level much less reliable than the correction to the other schooling levels. The "unadjusted" line refers to the Hispanic-white log wage gap we observe if we do not control for AFQT scores (column I in table 1). Therefore it is a horizontal line since it does not depend on the grade to which we are correcting the test score. The "adjusted" line refers to the Hispanic-white log wage gap we observe after we adjust for the AFQT scores corrected to different grades. 


\section{Figure 13D}

\section{Residual Hispanic-White Log Wage Gap in 1991 By Grade}

At Which We Evaluate The School-Corrected AFQT

NLSY79 Females Born After 1961

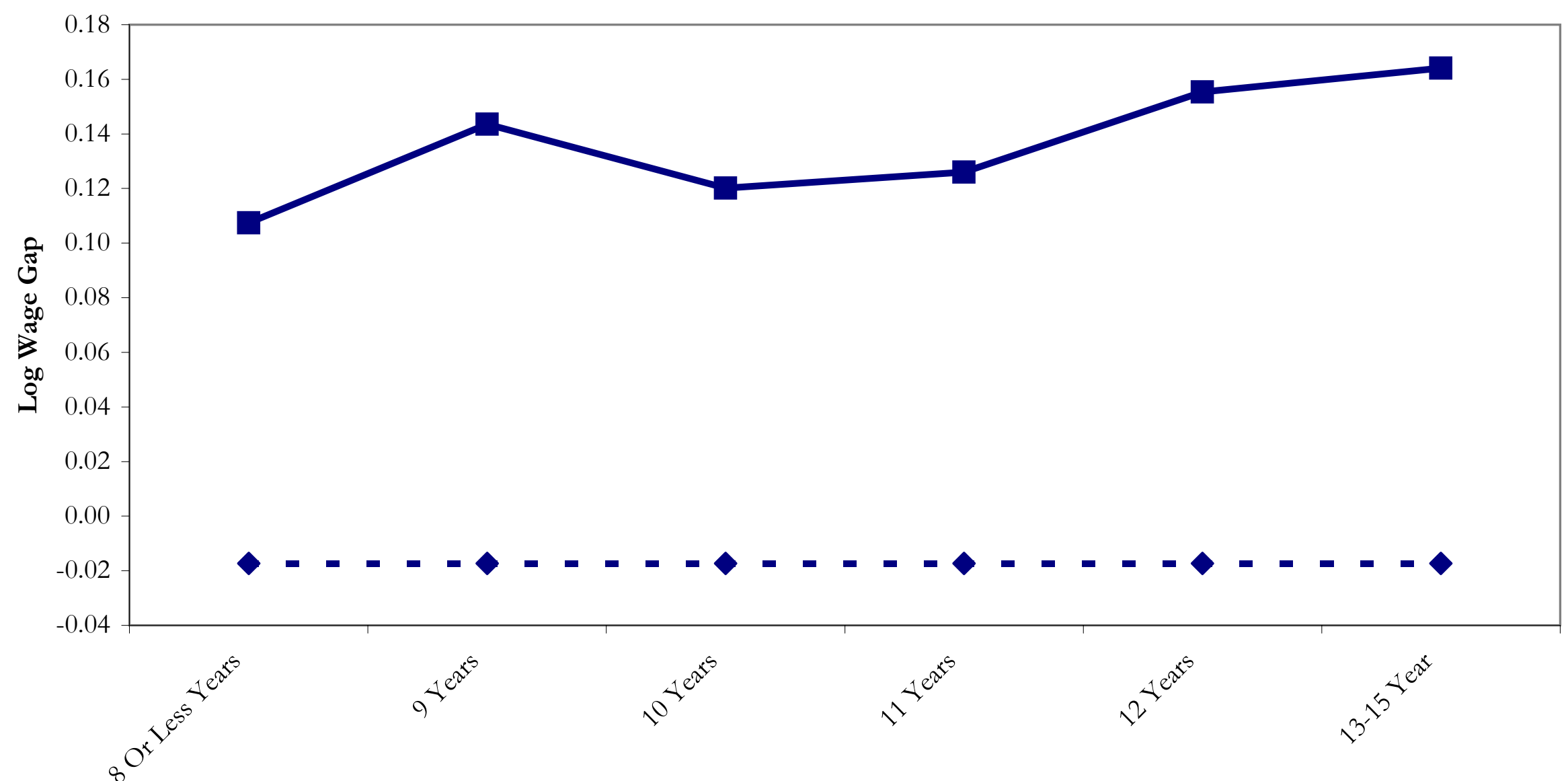

Grade At Which We Evaluate the Schooling-Corrected AFQT

$$
\boldsymbol{\sim} \text {-Adjusted - } \bullet \cdot \text { Unadjusted }
$$

Note: We have omitted the results for the " 16 or More" category because the low number of minorities in that cell make the correction of the test scores to that schooling level much less reliable than the correction to the other schooling levels. The "unadjusted" line refers to the Hispanic-white log wage gap we observe if we do not control for AFQT scores (column I in table 1). Therefore it is a horizontal line since it does not depend on the grade to which we are correcting the test score. The "adjusted" line refers to the Hispanic-white log wage gap we observe after we adjust for the AFQT scores corrected to different grades. 
Table 4

Change in the Black-White Log Wage Gap Induced by Controlling for Schooling-Corrected AFQT and Highest Grade Completed in 1990-2000

\begin{tabular}{|c|c|c|c|c|c|c|c|c|c|c|c|c|c|c|c|c|}
\hline \multicolumn{17}{|c|}{$\begin{array}{l}\text { NLSY Men born after } 1961 \\
\end{array}$} \\
\hline \multirow{2}{*}{ Year: } & \multicolumn{2}{|c|}{1990} & \multicolumn{2}{|c|}{1991} & \multicolumn{2}{|c|}{1992} & \multicolumn{2}{|c|}{1993} & \multicolumn{2}{|c|}{1994} & \multicolumn{2}{|c|}{1996} & \multicolumn{2}{|c|}{1998} & \multicolumn{2}{|c|}{2000} \\
\hline & I & II & I & II & I & II & I & II & I & II & I & II & I & II & I & II \\
\hline$\overline{\text { Black }}$ & $\begin{array}{c}-0.250 \\
(0.028)\end{array}$ & $\begin{array}{c}-0.144 \\
(0.028)\end{array}$ & $\begin{array}{c}-0.251 \\
(0.028)\end{array}$ & $\begin{array}{c}-0.158 \\
(0.028)\end{array}$ & $\begin{array}{c}-0.302 \\
(0.029)\end{array}$ & $\begin{array}{c}-0.189 \\
(0.028)\end{array}$ & $\begin{array}{c}-0.282 \\
(0.028)\end{array}$ & $\begin{array}{l}-0.182 \\
(0.028)\end{array}$ & $\begin{array}{l}-0.286 \\
(0.031)\end{array}$ & $\begin{array}{l}-0.175 \\
(0.031)\end{array}$ & $\begin{array}{c}-0.373 \\
(0.032)\end{array}$ & $\begin{array}{c}-0.241 \\
(0.031)\end{array}$ & $\begin{array}{c}-0.333 \\
(0.034)\end{array}$ & $\begin{array}{l}-0.175 \\
(0.032)\end{array}$ & $\begin{array}{c}-0.325 \\
(0.035)\end{array}$ & $\begin{array}{c}-0.194 \\
(0.032)\end{array}$ \\
\hline Hispanic & $\begin{array}{l}-0.174 \\
(0.032)\end{array}$ & $\begin{array}{l}-0.056 \\
(0.032)\end{array}$ & $\begin{array}{l}-0.113 \\
(0.032)\end{array}$ & $\begin{array}{c}0.005 \\
(0.032)\end{array}$ & $\begin{array}{l}-0.146 \\
(0.033)\end{array}$ & $\begin{array}{l}-0.032 \\
(0.032)\end{array}$ & $\begin{array}{l}-0.159 \\
(0.032)\end{array}$ & $\begin{array}{l}-0.044 \\
(0.032)\end{array}$ & $\begin{array}{l}-0.143 \\
(0.036)\end{array}$ & $\begin{array}{l}-0.018 \\
(0.035)\end{array}$ & $\begin{array}{l}-0.186 \\
(0.038)\end{array}$ & $\begin{array}{l}-0.056 \\
(0.036)\end{array}$ & $\begin{array}{l}-0.195 \\
(0.040)\end{array}$ & $\begin{array}{l}-0.040 \\
(0.037)\end{array}$ & $\begin{array}{l}-0.215 \\
(0.040)\end{array}$ & $\begin{array}{c}-0.070 \\
(0.037)\end{array}$ \\
\hline Age & - & $\begin{array}{c}0.062 \\
(0.014)\end{array}$ & - & $\begin{array}{c}0.041 \\
(0.014)\end{array}$ & - & $\begin{array}{c}0.052 \\
(0.014)\end{array}$ & - & $\begin{array}{c}0.042 \\
(0.014)\end{array}$ & - & $\begin{array}{c}0.036 \\
(0.016)\end{array}$ & - & $\begin{array}{c}0.033 \\
(0.016)\end{array}$ & - & $\begin{array}{c}0.031 \\
(0.017)\end{array}$ & - & $\begin{array}{c}0.024 \\
(0.016)\end{array}$ \\
\hline AFQT & - & $\begin{array}{c}0.096 \\
(0.015)\end{array}$ & - & $\begin{array}{c}0.079 \\
(0.015)\end{array}$ & - & $\begin{array}{c}0.097 \\
(0.015)\end{array}$ & - & $\begin{array}{c}0.082 \\
(0.015)\end{array}$ & - & $\begin{array}{c}0.098 \\
(0.016)\end{array}$ & - & $\begin{array}{c}0.093 \\
(0.017)\end{array}$ & - & $\begin{array}{c}0.130 \\
(0.017)\end{array}$ & - & $\begin{array}{c}0.119 \\
(0.017)\end{array}$ \\
\hline $\mathrm{AFQT}^{2}$ & - & $\begin{array}{l}-0.015 \\
(0.010)\end{array}$ & - & $\begin{array}{l}-0.005 \\
(0.010)\end{array}$ & - & $\begin{array}{l}-0.001 \\
(0.010)\end{array}$ & - & $\begin{array}{l}-0.001 \\
(0.010)\end{array}$ & - & $\begin{array}{c}0.010 \\
(0.011)\end{array}$ & - & $\begin{array}{c}0.005 \\
(0.012)\end{array}$ & - & $\begin{array}{c}0.013 \\
(0.012)\end{array}$ & - & $\begin{array}{c}0.008 \\
(0.012)\end{array}$ \\
\hline HGC & - & $\begin{array}{c}0.044 \\
(0.006)\end{array}$ & - & $\begin{array}{c}0.040 \\
(0.006)\end{array}$ & - & $\begin{array}{c}0.043 \\
(0.006)\end{array}$ & - & $\begin{array}{c}0.047 \\
(0.006)\end{array}$ & - & $\begin{array}{c}0.046 \\
(0.006)\end{array}$ & - & $\begin{array}{c}0.065 \\
(0.006)\end{array}$ & - & $\begin{array}{c}0.066 \\
(0.007)\end{array}$ & - & $\begin{array}{c}0.066 \\
(0.006)\end{array}$ \\
\hline Constant & $\begin{array}{c}2.375 \\
(0.017) \\
\end{array}$ & $\begin{array}{c}0.113 \\
(0.390) \\
\end{array}$ & $\begin{array}{c}2.372 \\
(0.017) \\
\end{array}$ & $\begin{array}{c}0.668 \\
(0.410) \\
\end{array}$ & $\begin{array}{c}2.404 \\
(0.017) \\
\end{array}$ & $\begin{array}{c}0.281 \\
(0.422) \\
\end{array}$ & $\begin{array}{c}2.423 \\
(0.017)\end{array}$ & $\begin{array}{c}0.501 \\
(0.431)\end{array}$ & $\begin{array}{c}2.458 \\
(0.018)\end{array}$ & $\begin{array}{c}0.679 \\
(0.488) \\
\end{array}$ & $\begin{array}{c}2.533 \\
(0.019) \\
\end{array}$ & $\begin{array}{c}0.540 \\
(0.531) \\
\end{array}$ & $\begin{array}{c}2.589 \\
(0.020) \\
\end{array}$ & $\begin{array}{c}0.549 \\
(0.586) \\
\end{array}$ & $\begin{array}{c}2.629 \\
(0.020) \\
\end{array}$ & $\begin{array}{c}0.802 \\
(0.608) \\
\end{array}$ \\
\hline $\mathrm{N}$ & 1538 & 1504 & 1553 & 1513 & 1536 & 1503 & 1542 & 1504 & 1522 & 1485 & 1554 & 1519 & 1494 & 1462 & 1438 & 1404 \\
\hline \multicolumn{17}{|c|}{ NLSY Women born after 1961} \\
\hline \multirow[t]{2}{*}{ Year: } & \multicolumn{2}{|c|}{1990} & \multicolumn{2}{|c|}{1991} & \multicolumn{2}{|c|}{1992} & \multicolumn{2}{|c|}{1993} & \multicolumn{2}{|c|}{1994} & \multicolumn{2}{|c|}{1996} & \multicolumn{2}{|c|}{1998} & \multicolumn{2}{|c|}{2000} \\
\hline & I & II & I & II & I & II & I & II & I & II & I & II & I & II & I & II \\
\hline Black & $\begin{array}{l}-0.172 \\
(0.031)\end{array}$ & $\begin{array}{c}-0.081 \\
(0.030)\end{array}$ & $\begin{array}{l}-0.200 \\
(0.032)\end{array}$ & $\begin{array}{c}-0.101 \\
(0.032)\end{array}$ & $\begin{array}{c}-0.201 \\
(0.031)\end{array}$ & $\begin{array}{c}-0.131 \\
(0.030)\end{array}$ & $\begin{array}{l}-0.167 \\
(0.035)\end{array}$ & $\begin{array}{l}-0.073 \\
(0.033)\end{array}$ & $\begin{array}{l}-0.148 \\
(0.035)\end{array}$ & $\begin{array}{l}-0.069 \\
(0.034)\end{array}$ & $\begin{array}{l}-0.147 \\
(0.035)\end{array}$ & $\begin{array}{l}-0.035 \\
(0.033)\end{array}$ & $\begin{array}{l}-0.201 \\
(0.034)\end{array}$ & $\begin{array}{l}-0.088 \\
(0.032)\end{array}$ & $\begin{array}{l}-0.200 \\
(0.036)\end{array}$ & $\begin{array}{l}-0.086 \\
(0.034)\end{array}$ \\
\hline Hispanic & $\begin{array}{l}-0.003 \\
(0.035)\end{array}$ & $\begin{array}{c}0.120 \\
(0.033)\end{array}$ & $\begin{array}{l}-0.017 \\
(0.037)\end{array}$ & $\begin{array}{c}0.111 \\
(0.036)\end{array}$ & $\begin{array}{l}-0.059 \\
(0.036)\end{array}$ & $\begin{array}{c}0.073 \\
(0.033)\end{array}$ & $\begin{array}{c}0.009 \\
(0.039)\end{array}$ & $\begin{array}{c}0.139 \\
(0.037)\end{array}$ & $\begin{array}{l}-0.018 \\
(0.040)\end{array}$ & $\begin{array}{c}0.118 \\
(0.038)\end{array}$ & $\begin{array}{l}-0.006 \\
(0.041)\end{array}$ & $\begin{array}{c}0.137 \\
(0.037)\end{array}$ & $\begin{array}{l}-0.069 \\
(0.039)\end{array}$ & $\begin{array}{c}0.091 \\
(0.036)\end{array}$ & $\begin{array}{l}-0.064 \\
(0.041)\end{array}$ & $\begin{array}{c}0.096 \\
(0.038)\end{array}$ \\
\hline Age & - & $\begin{array}{c}0.013 \\
(0.015)\end{array}$ & - & $\begin{array}{c}0.036 \\
(0.016)\end{array}$ & - & $\begin{array}{c}0.013 \\
(0.015)\end{array}$ & $\begin{array}{l}- \\
-\end{array}$ & $\begin{array}{c}0.014 \\
(0.017)\end{array}$ & $\begin{array}{l}- \\
-\end{array}$ & $\begin{array}{c}0.006 \\
(0.017)\end{array}$ & - & $\begin{array}{l}-0.009 \\
(0.017)\end{array}$ & - & $\begin{array}{c}0.013 \\
(0.017)\end{array}$ & - & $\begin{array}{c}-0.017 \\
(0.017)\end{array}$ \\
\hline AFQT & - & $\begin{array}{c}0.106 \\
(0.017)\end{array}$ & - & $\begin{array}{c}0.113 \\
(0.019)\end{array}$ & - & $\begin{array}{c}0.094 \\
(0.017)\end{array}$ & - & $\begin{array}{c}0.121 \\
(0.019)\end{array}$ & - & $\begin{array}{c}0.111 \\
(0.020)\end{array}$ & - & $\begin{array}{c}0.130 \\
(0.019)\end{array}$ & - & $\begin{array}{c}0.119 \\
(0.019)\end{array}$ & - & $\begin{array}{c}0.127 \\
(0.020)\end{array}$ \\
\hline $\mathrm{AFQT}^{2}$ & - & $\begin{array}{l}-0.001 \\
(0.013)\end{array}$ & - & $\begin{array}{l}-0.002 \\
(0.014)\end{array}$ & - & $\begin{array}{l}-0.007 \\
(0.013)\end{array}$ & - & $\begin{array}{l}-0.009 \\
(0.014)\end{array}$ & - & $\begin{array}{l}-0.026 \\
(0.015)\end{array}$ & - & $\begin{array}{c}0.003 \\
(0.014)\end{array}$ & - & $\begin{array}{c}0.004 \\
(0.014)\end{array}$ & - & $\begin{array}{l}-0.007 \\
(0.014)\end{array}$ \\
\hline HGC & - & $\begin{array}{c}0.063 \\
(0.006)\end{array}$ & - & $\begin{array}{c}0.064 \\
(0.006)\end{array}$ & - & $\begin{array}{c}0.075 \\
(0.006)\end{array}$ & - & $\begin{array}{c}0.075 \\
(0.007)\end{array}$ & - & $\begin{array}{c}0.081 \\
(0.007)\end{array}$ & - & $\begin{array}{c}0.081 \\
(0.006)\end{array}$ & - & $\begin{array}{c}0.076 \\
(0.006)\end{array}$ & - & $\begin{array}{c}0.073 \\
(0.006)\end{array}$ \\
\hline Constant & $\begin{array}{c}2.141 \\
(0.019) \\
\end{array}$ & $\begin{array}{c}0.913 \\
(0.413) \\
\end{array}$ & $\begin{array}{c}2.175 \\
(0.020) \\
\end{array}$ & $\begin{array}{c}0.270 \\
(0.460) \\
\end{array}$ & $\begin{array}{c}2.193 \\
(0.019) \\
\end{array}$ & $\begin{array}{c}0.784 \\
(0.443) \\
\end{array}$ & $\begin{array}{c}2.174 \\
(0.021) \\
\end{array}$ & $\begin{array}{c}0.720 \\
(0.508) \\
\end{array}$ & $\begin{array}{c}2.218 \\
(0.022) \\
\end{array}$ & $\begin{array}{c}0.932 \\
(0.538) \\
\end{array}$ & $\begin{array}{c}2.246 \\
(0.022) \\
\end{array}$ & $\begin{array}{c}1.397 \\
(0.558) \\
\end{array}$ & $\begin{array}{c}2.311 \\
(0.021) \\
\end{array}$ & $\begin{array}{c}0.802 \\
(0.583) \\
\end{array}$ & $\begin{array}{c}2.339 \\
(0.022) \\
\end{array}$ & $\begin{array}{r}1.928 \\
(0.643) \\
\end{array}$ \\
\hline $\mathrm{N}$ & 1356 & 1325 & 1335 & 1299 & 1317 & 1278 & 1319 & & 1318 & 1286 & 1381 & 1343 & 1370 & 1328 & 1316 & 1276 \\
\hline
\end{tabular}

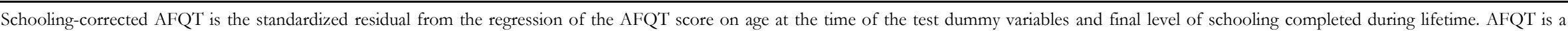

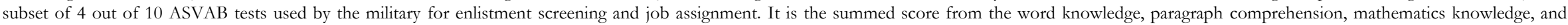
arithmetic reasoning ASVAB tests. All wages are in 1993 dollars. HGC is the highest observed level of schooling completed during the individual's lifetime. 


\section{TABLE 5 - MEANS AND ST DEV OF EXPECTATIONS \\ BY RACE AND SEX \\ NLSY97 ROUND1}

\begin{tabular}{|c|c|c|c|c|c|}
\hline & BLACKS & HISPANICS & WHITES & MALES & FEMALES \\
\hline " & $\begin{array}{c}91.75 \\
(22.79)\end{array}$ & $\begin{array}{c}88.35 \\
(26.33)\end{array}$ & $\begin{array}{c}93.72 \\
(21.31)\end{array}$ & $\begin{array}{c}91.67 \\
(23.32)\end{array}$ & $\begin{array}{c}92.55 \\
(22.30)\end{array}$ \\
\hline E1: Working for pay $>20 \mathrm{hs}$ wk and enrolled & $\begin{array}{c}62.77 \\
(32.44)\end{array}$ & $\begin{array}{c}60.00 \\
(31.02)\end{array}$ & $\begin{array}{c}59.11 \\
(33.43)\end{array}$ & $\begin{array}{c}60.84 \\
(32.00)\end{array}$ & $\begin{array}{c}58.86 \\
(33.65)\end{array}$ \\
\hline E1: Working for pay $>20 \mathrm{hs}$ wk and not enrolled & $\begin{array}{c}77.01 \\
(31.44)\end{array}$ & $\begin{array}{c}76.39 \\
(30.18)\end{array}$ & $\begin{array}{c}83.11 \\
(27.58)\end{array}$ & $\begin{array}{c}80.09 \\
(28.88)\end{array}$ & $\begin{array}{c}79.78 \\
(29.95)\end{array}$ \\
\hline E1: Got pregnant & $\begin{array}{c}7.99 \\
(20.43)\end{array}$ & $\begin{array}{c}7.78 \\
(17.64)\end{array}$ & $\begin{array}{c}4.68 \\
(12.99)\end{array}$ & $\begin{array}{l}0.00 \\
0.00\end{array}$ & $\begin{array}{c}6.32 \\
(16.53)\end{array}$ \\
\hline E1: Got someone pregnant & $\begin{array}{c}13.52 \\
(21.75)\end{array}$ & $\begin{array}{c}12.33 \\
(20.65)\end{array}$ & $\begin{array}{c}6.27 \\
(14.77)\end{array}$ & $\begin{array}{c}9.46 \\
(18.39)\end{array}$ & $\begin{array}{l}0.00 \\
0.00\end{array}$ \\
\hline E1: Seriously drunk at least once & $\begin{array}{c}11.64 \\
(23.77)\end{array}$ & $\begin{array}{c}20.37 \\
(29.78)\end{array}$ & $\begin{array}{c}24.12 \\
(33.81)\end{array}$ & $\begin{array}{c}21.55 \\
(32.06)\end{array}$ & $\begin{array}{c}18.00 \\
(29.44)\end{array}$ \\
\hline E1: Victim of violent crime & $\begin{array}{c}16.16 \\
(22.99)\end{array}$ & $\begin{array}{c}16.11 \\
(21.92)\end{array}$ & $\begin{array}{c}13.36 \\
(18.89)\end{array}$ & $\begin{array}{c}15.40 \\
(21.44)\end{array}$ & $\begin{array}{c}13.97 \\
(20.04)\end{array}$ \\
\hline E1: Arrested & $\begin{array}{c}12.14 \\
(20.55)\end{array}$ & $\begin{array}{c}11.43 \\
(19.49)\end{array}$ & $\begin{array}{c}8.74 \\
(16.08)\end{array}$ & $\begin{array}{c}13.73 \\
(20.69)\end{array}$ & $\begin{array}{c}6.65 \\
(14.33)\end{array}$ \\
\hline E1: Dead from any cause & $\begin{array}{c}22.53 \\
(25.35)\end{array}$ & $\begin{array}{c}19.02 \\
(23.00)\end{array}$ & $\begin{array}{c}16.56 \\
(20.36)\end{array}$ & $\begin{array}{c}17.55 \\
(21.92)\end{array}$ & $\begin{array}{c}19.75 \\
(23.03)\end{array}$ \\
\hline${ }^{* \star} \mathrm{E} 2:$ Received a high school diploma & $\begin{array}{c}92.99 \\
(19.45)\end{array}$ & $\begin{array}{c}88.92 \\
(23.64)\end{array}$ & $\begin{array}{c}95.44 \\
(15.57)\end{array}$ & $\begin{array}{c}92.33 \\
(19.63)\end{array}$ & $\begin{array}{c}94.57 \\
(17.58)\end{array}$ \\
\hline E2: Served time in jail or prison & $\begin{array}{c}5.03 \\
(13.00)\end{array}$ & $\begin{array}{c}7.53 \\
(16.35)\end{array}$ & $\begin{array}{c}4.54 \\
(11.76)\end{array}$ & $\begin{array}{c}7.18 \\
(15.20)\end{array}$ & $\begin{array}{c}3.40 \\
(10.41)\end{array}$ \\
\hline E2: Mothered or Fathered a baby & $\begin{array}{c}21.20 \\
(29.34)\end{array}$ & $\begin{array}{c}21.00 \\
(27.69)\end{array}$ & $\begin{array}{c}14.86 \\
(23.14)\end{array}$ & $\begin{array}{c}19.22 \\
(25.63)\end{array}$ & $\begin{array}{c}16.28 \\
(26.30)\end{array}$ \\
\hline E2: Dead from any cause & $\begin{array}{c}22.27 \\
(24.73)\end{array}$ & $\begin{array}{c}21.48 \\
(23.60)\end{array}$ & $\begin{array}{c}19.01 \\
(20.72)\end{array}$ & $\begin{array}{c}19.60 \\
(22.20)\end{array}$ & $\begin{array}{c}21.08 \\
(22.75)\end{array}$ \\
\hline${ }^{* \star \star}$ E3: Earned a 4-yr college degree & $\begin{array}{c}74.22 \\
(31.44)\end{array}$ & $\begin{array}{c}66.93 \\
(31.59)\end{array}$ & $\begin{array}{c}73.75 \\
(31.50)\end{array}$ & $\begin{array}{c}68.75 \\
(32.02)\end{array}$ & $\begin{array}{c}76.90 \\
(30.37)\end{array}$ \\
\hline E3: Working for pay > 20hs wk 97 & $\begin{array}{c}90.48 \\
(20.05)\end{array}$ & $\begin{array}{c}89.72 \\
(19.23)\end{array}$ & $\begin{array}{c}94.39 \\
(13.71)\end{array}$ & $\begin{array}{c}92.81 \\
(16.05)\end{array}$ & $\begin{array}{c}91.85 \\
(17.93)\end{array}$ \\
\hline P1: Enrolled in School & $\begin{array}{c}90.68 \\
(23.70)\end{array}$ & $\begin{array}{c}89.39 \\
(25.08)\end{array}$ & $\begin{array}{c}94.03 \\
(20.07)\end{array}$ & $\begin{array}{c}90.80 \\
(23.80)\end{array}$ & $\begin{array}{c}93.64 \\
(20.48)\end{array}$ \\
\hline P1: Working for pay $>20 \mathrm{hs}$ wk and enrolled & $\begin{array}{c}51.42 \\
(34.84)\end{array}$ & $\begin{array}{c}50.52 \\
(37.10)\end{array}$ & $\begin{array}{c}42.65 \\
(38.16)\end{array}$ & $\begin{array}{c}47.14 \\
(37.05)\end{array}$ & $\begin{array}{c}45.09 \\
(37.54)\end{array}$ \\
\hline P2: Received a high school diploma & $\begin{array}{c}91.51 \\
(21.14)\end{array}$ & $\begin{array}{c}91.94 \\
(19.97)\end{array}$ & $\begin{array}{c}96.19 \\
(15.10)\end{array}$ & $\begin{array}{c}93.12 \\
(19.43)\end{array}$ & $\begin{array}{c}95.13 \\
(16.31)\end{array}$ \\
\hline P2: Served time in jail or prison & $\begin{array}{c}4.77 \\
(14.35)\end{array}$ & $\begin{array}{c}3.87 \\
(12.99)\end{array}$ & $\begin{array}{c}2.62 \\
(9.39)\end{array}$ & $\begin{array}{c}4.84 \\
(13.93)\end{array}$ & $\begin{array}{c}2.06 \\
(8.76)\end{array}$ \\
\hline P2: Mothered or Fathered a baby & $\begin{array}{c}17.55 \\
(28.84)\end{array}$ & $\begin{array}{c}19.32 \\
(27.81)\end{array}$ & $\begin{array}{c}12.58 \\
(21.55)\end{array}$ & $\begin{array}{c}15.54 \\
(24.66)\end{array}$ & $\begin{array}{c}14.94 \\
(25.68)\end{array}$ \\
\hline P3: Earned a 4-yr college degree & $\begin{array}{c}68.29 \\
(33.44)\end{array}$ & $\begin{array}{c}67.15 \\
(32.35)\end{array}$ & $\begin{array}{c}69.85 \\
(32.29)\end{array}$ & $\begin{array}{c}65.68 \\
(34.03)\end{array}$ & $\begin{array}{c}72.77 \\
(30.63)\end{array}$ \\
\hline P3: Working for pay > 20hs wk 97 & $\begin{array}{c}93.22 \\
(16.17)\end{array}$ & $\begin{array}{c}92.89 \\
(17.82)\end{array}$ & $\begin{array}{c}94.95 \\
(13.30)\end{array}$ & $\begin{array}{c}95.87 \\
(12.93)\end{array}$ & $\begin{array}{c}92.18 \\
(16.96)\end{array}$ \\
\hline
\end{tabular}

* E1 means expectations a year from interview date. P1 means expectations of youth's parent a year from interview date.

** E2 means expectations by youth's 20th birthday. P2 means expectations of youth's parent by youth's 20th birthday.

${ }^{* * *}$ E3 means expectations by youth's 30th birthday. P3 means expectations from youth's parent by youth's 30th birthday.

${ }^{1}$ In round 1, respondents who were born in 1980 or 1981 were surveyed on their beliefs about the future. Asked to assess the probability that certain events would occur in a specified time period, the respondents were instructed to use a scale from 0 (impossible) to 100 


\section{Table 6A}

\section{Table of Means for Males By Race \\ Expectation ${ }^{1}$ Of Being Enrolled Next Year NLSY97 Round 1}

\begin{tabular}{l|cc|cc|cc}
\hline & BLACKS & ACTUAL & HISPANICS & ACTUAL & WHITES & ACTUAL \\
\hline \hline All individuals & 0.912 & 0.734 & 0.881 & 0.717 & 0.934 & 0.790 \\
& $(0.232)$ & $(0.442)$ & $(0.265)$ & $(0.451)$ & $(0.219)$ & $(0.407)$ \\
Individuals Enrolled in 1997 & 0.936 & 0.764 & 0.915 & 0.758 & 0.957 & 0.819 \\
& $(0.188)$ & $(0.425)$ & $(0.217)$ & $(0.429)$ & $(0.173)$ & $(0.385)$ \\
\hline
\end{tabular}

${ }^{1}$ In round 1 , respondents who were born in 1980 or 1981 were surveyed on their beliefs about the future. Asked to assess the probability that certain events would occur in a specified time period, the respondents were instructed to use a scale from 0 (impossible) to 100 (certain).

\section{Table 6B}

\section{Table of Means For Males by Race}

\section{Parental Expectation ${ }^{1}$ of Youth Being Enrolled Next Year NLSY97 Round1}

\begin{tabular}{l|cc|cc|cc}
\hline & BLACKS & ACTUAL & HISPANICS & ACTUAL & WHITES & ACTUAL \\
\hline \hline All individuals & 0.885 & 0.734 & 0.880 & 0.717 & 0.930 & 0.790 \\
& $(0.255)$ & $(0.442)$ & $(0.259)$ & $(0.451)$ & $(0.217)$ & $(0.407)$ \\
Individuals Enrolled in 1997 & 0.909 & 0.764 & 0.911 & 0.758 & 0.954 & 0.819 \\
& $(0.221)$ & $(0.425)$ & $(0.220)$ & $(0.429)$ & $(0.169)$ & $(0.385)$ \\
\hline
\end{tabular}

${ }^{1}$ In round 1 , respondents who were born in 1980 or 1981 were surveyed on their beliefs about the future. Asked to assess the probability that certain events would occur in a specified time period, the respondents were instructed to use a scale from 0 (impossible) to 100 (certain). 


\section{Figure 14A \\ Child's Own Expected Educational Level at Age 10 by Race and Sex}

Children of NLSY79

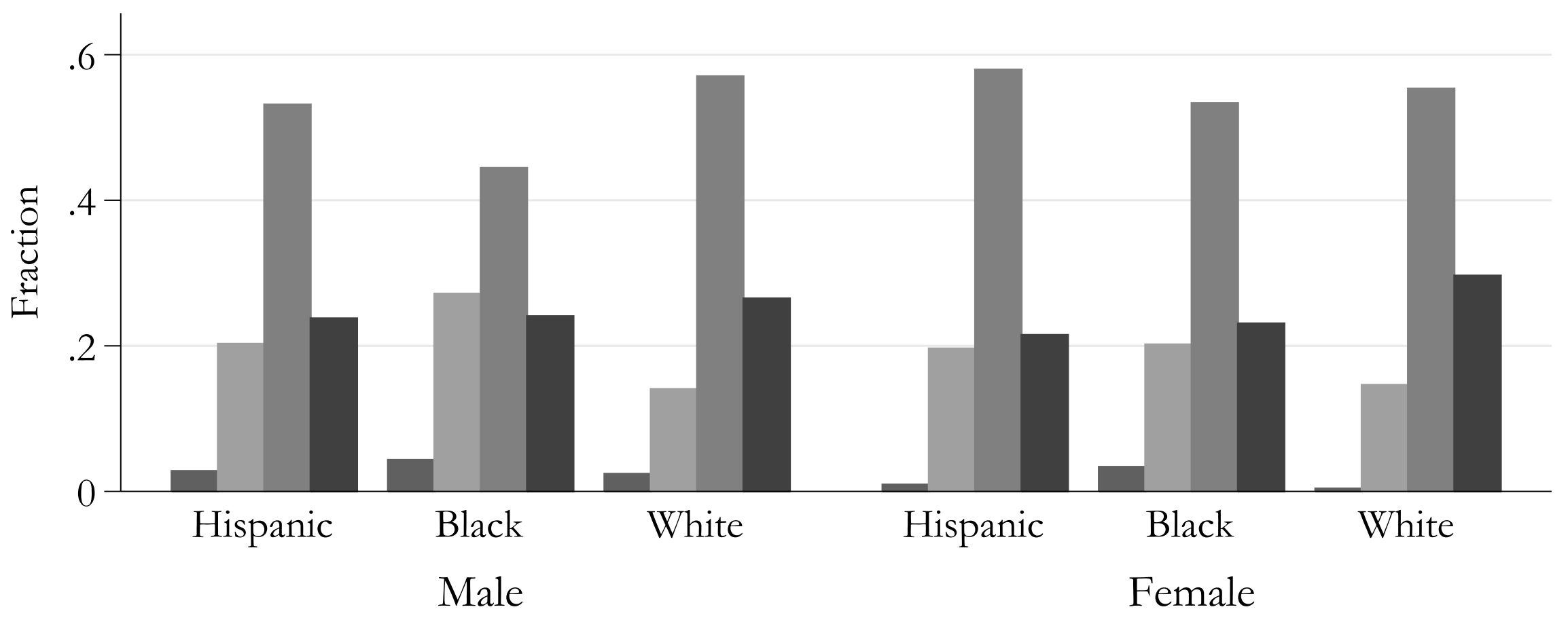

\begin{tabular}{|l|l|}
\hline $\begin{array}{l}\text { Drop Out } \\
\text { Some College or 4-Year College Graduate }\end{array}$ & High School Graduate \\
& More than 4-Year College \\
\hline
\end{tabular}

The height of the bar is produced by dividing the number of people who report falling in a particular educational expectation cell by the total number of people in their race-sex group. 


\section{Figure 14B}

Mother's Expected Educational Level For the Child at Age 6 by Race and Sex

Children of NLSY79

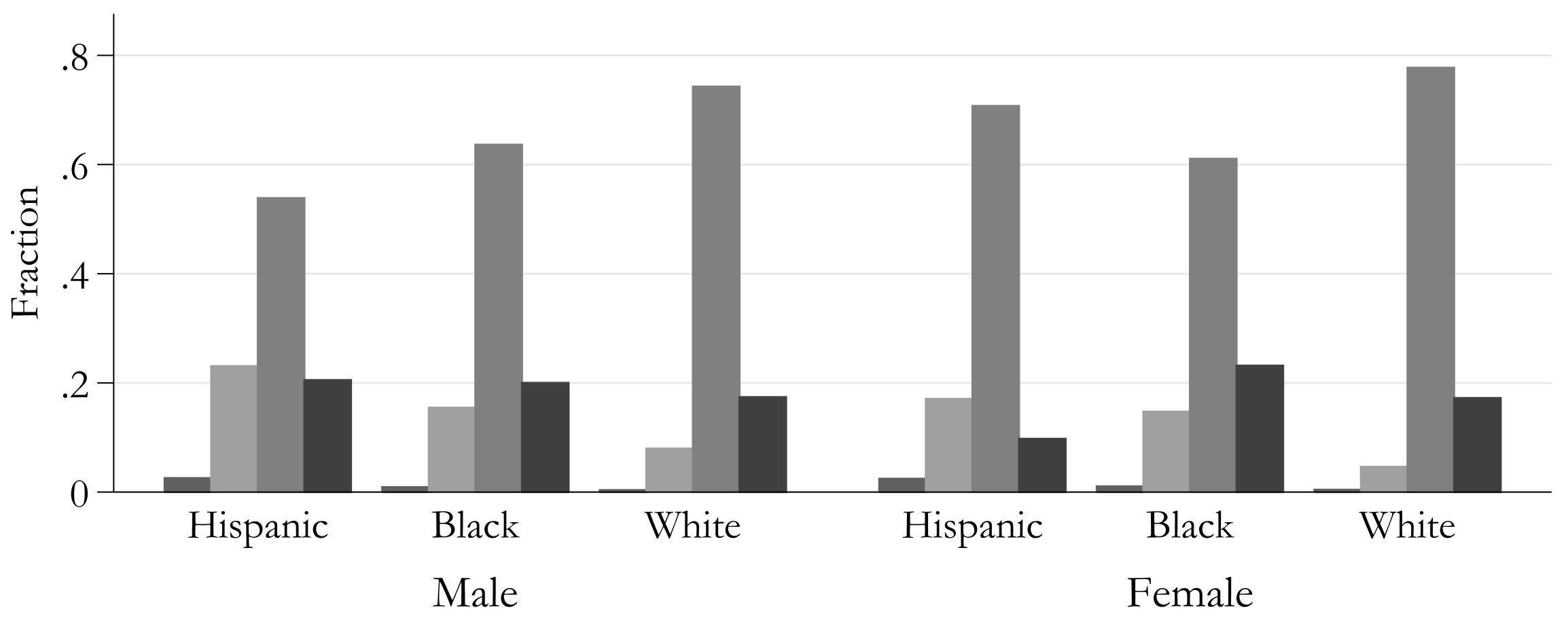

\begin{tabular}{|l|l|}
\hline Drop Out & High School Graduate \\
Some College or 4-Year College Graduate & More than 4-Year College \\
\hline
\end{tabular}

The height of the bar is produced by dividing the number of people who report falling in a particular educational expectation cell by the total number of people in their race-sex group. 
Figure 14C

Young Adult's Own Expected Educational Level at Age 17 by Race and Sex

Children of NLSY79

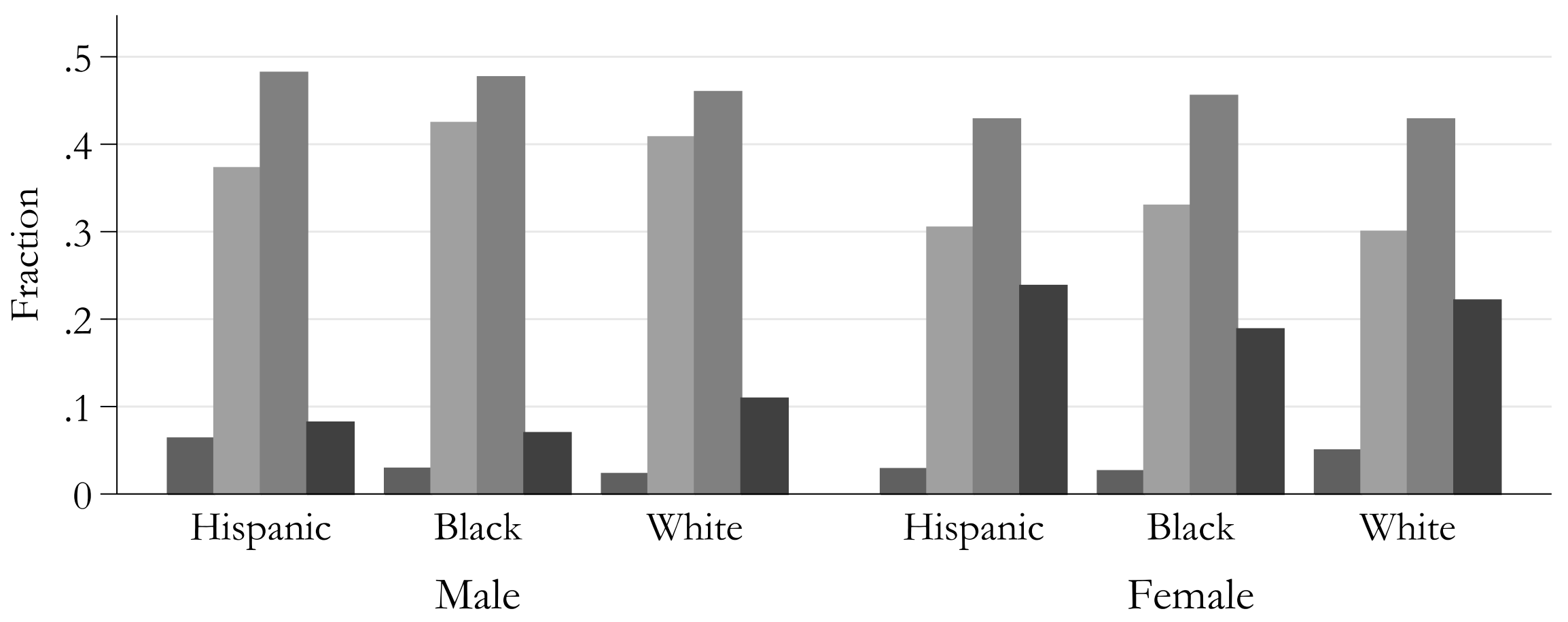

\begin{tabular}{|l|l|}
\hline Drop Out & High School Graduate \\
Some College or 4-Year College Graduate & More than 4-Year College \\
\hline
\end{tabular}

The height of the bar is produced by dividing the number of people who report falling in a particular educational expectaion cell by the total number of people in their race-sex group. 


\section{Figure 15A \\ Percentile Antisocial Behavior Score By Race and Age Group Children of NLSY79 Males}

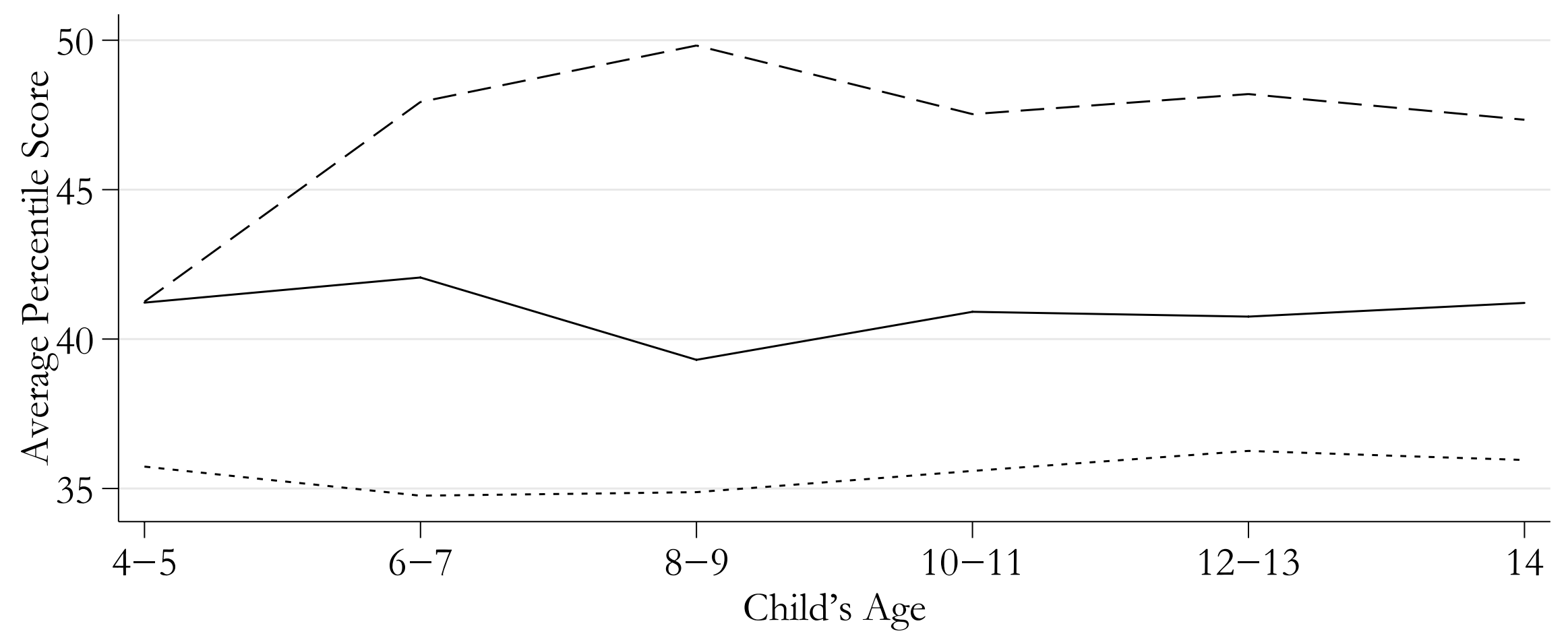

- Hispanic - - - - Black …....... White

Mothers were asked 28 age-specific questions about frequency, range and type of specific behavior problems that children age four and over may have exhibited in the previous three months. Factor analysis was used to determine six clusters of questions. This test is one such cluster. The responses for each cluster were dichotomized and summed to produce a raw score. The percentile score was then calculated separately for each sex at each age from the raw score A higher percentile score indicates a higher incidence of problems. 


\section{Figure 15B \\ Percentile Antisocial Behavior Score By Race and Age Group}

Children of NLSY79 Females

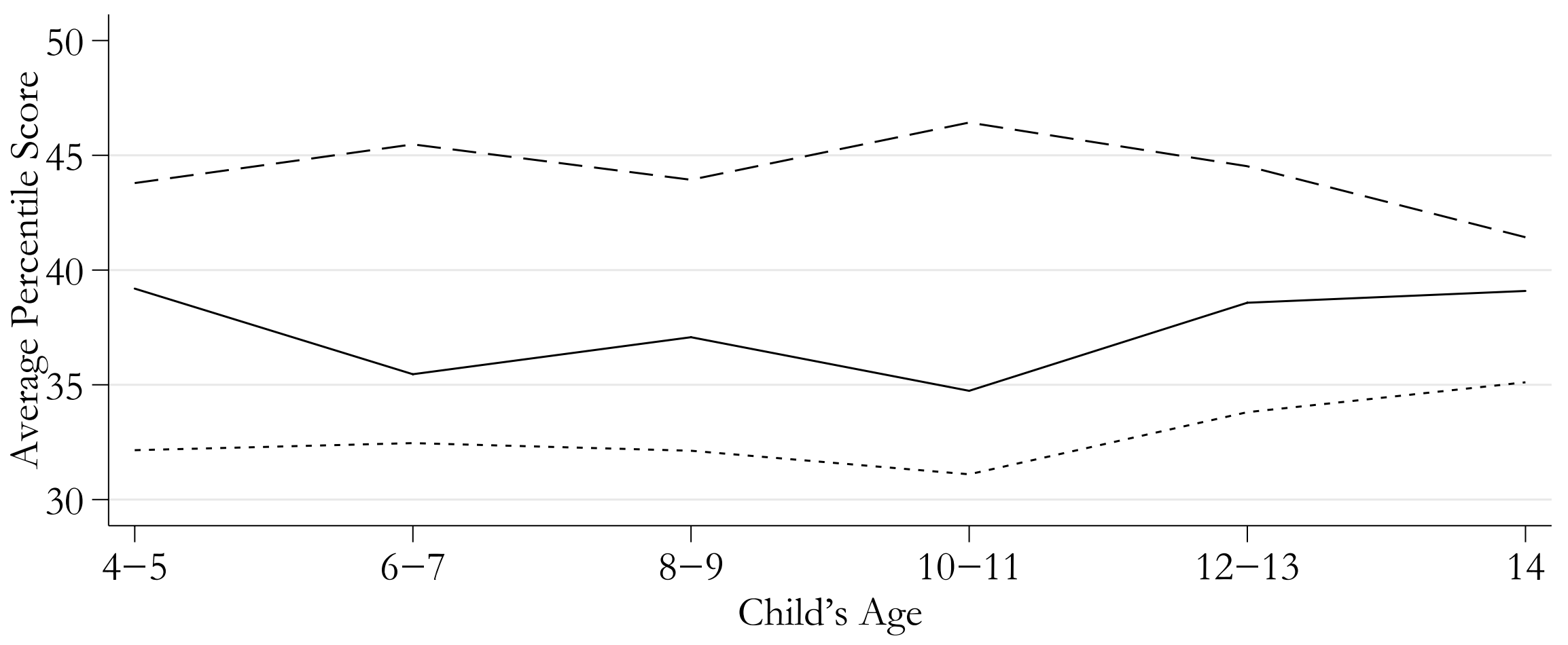

$$
\text { Hispanic - - - - Black …........ White }
$$

Mothers were asked 28 age-specific questions about frequency, range and type of specific behavior problems that children age four and over may have exhibited in the previous three months. Factor analysis was used to determine six clusters of questions. This test is one such cluster. The responses for each cluster were dichotomized and summed to produce a raw score. The percentile score was then calculated separately for each sex at each age from the raw score A higher percentile score indicates a higher incidence of problems. 


\section{Figure 16A \\ Adjusted Percentile Antisocial Behavior Score By Race and Age Group}

Children of NLSY79 Males

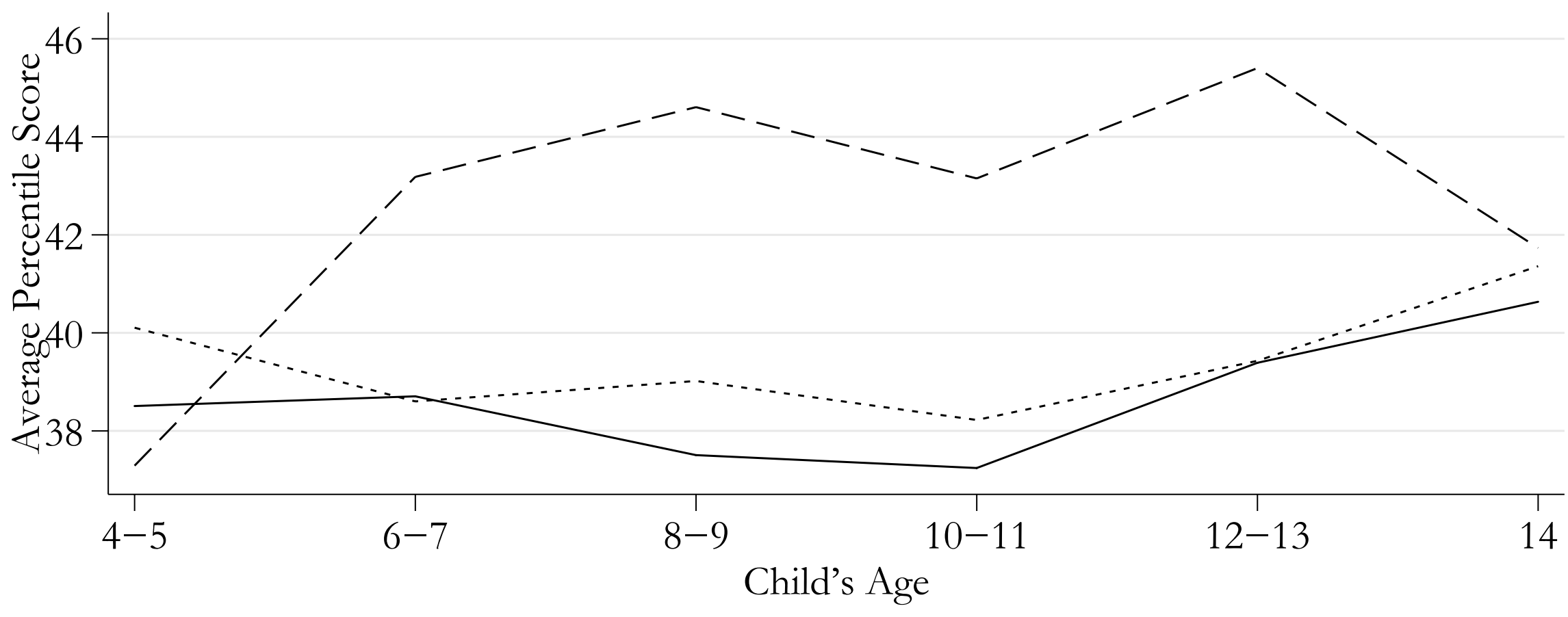

$$
\text { Hispanic - - - - Black .......... White }
$$

Adjusted by permanent family income, mother's education and age-corrected AFQT, and home score.

Adjusted indicates that we equalized the family background characteristics across all race groups by setting them at the mean to purge the effect of family environment disparities. Permanent income is constructed by taking the average of annual family income discounted to child's age 0 using a 10\% discount rate. Age-corrected AFQT is the standardized residual from the regression of the raw AFQT score on age at the time of the test dummy variables. Home score is an index of quality of the child's home environment. 


\section{Figure 16B \\ Adjusted Percentile Antisocial Behavior Score By Race and Age Group \\ Children of NLSY79 Females}

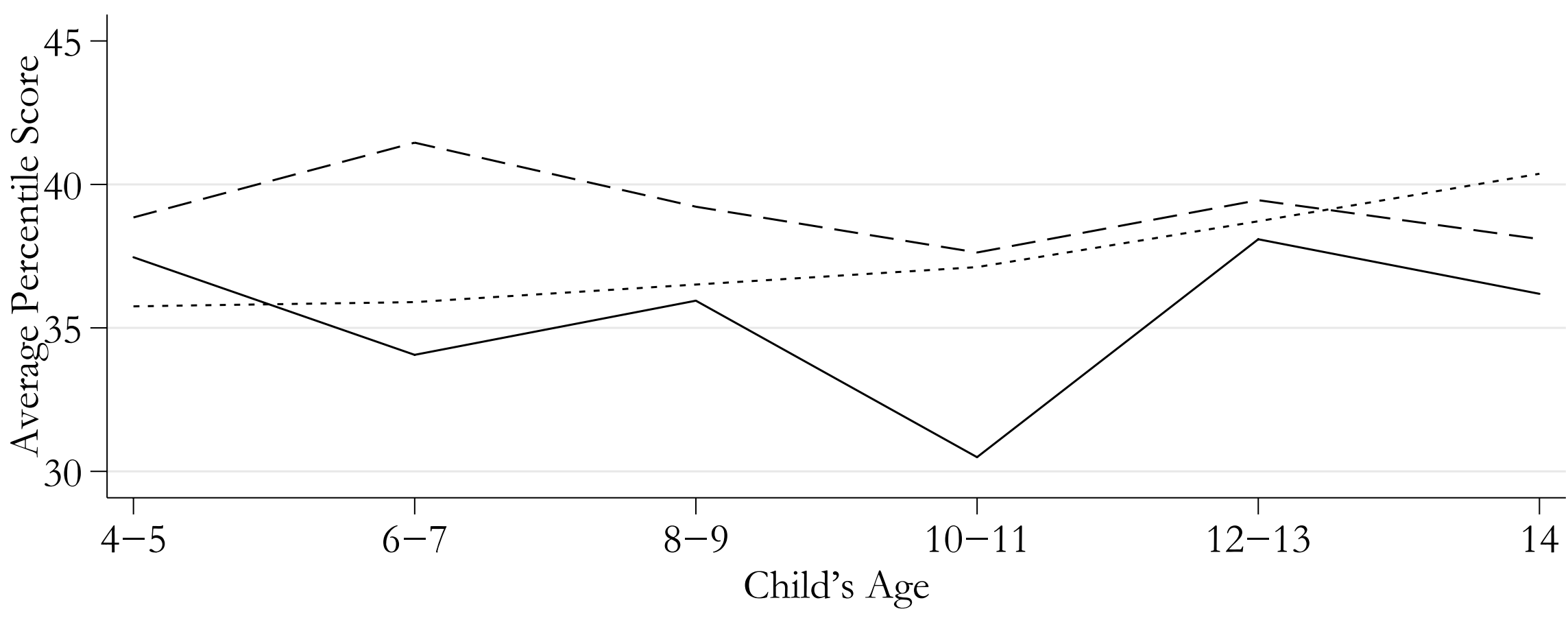

$$
\text { Hispanic - - - - Black .......... White }
$$

Adjusted by permanent family income, mother's education and age-corrected AFQT, and home score.

Adjusted indicates that we equalized the family background characteristics across all race groups by setting them at the mean to purge the effect of family environment disparities. Permanent income is constructed by taking the average of annual family income discounted to child's age 0 using a 10\% discount rate. Age-corrected AFQT is the standardized residual from the regression of the raw AFQT score on age at the time of the test dummy variables. Home score is an index of quality of the child's home environment. 